Ecosystem functioning along gradients of increasing hypoxia and changing soft-sediment community types

\title{
Norkko, Joanna
}

$2019-11$

Norkko , J , Pilditch , C A , Gammal , J , Rosenberg , R, Enemar , A, Magnussond, M , Granberg , M E , Lindgren , J F , Agrenius , S \& Norkko , A 2019 , ' Ecosystem functioning along gradients of increasing hypoxia and changing soft-sediment community types ' , Journal of Sea Research , vol. 153 , 101781 . https://doi.org/10.1016/j.seares.2019.101781

http://hdl.handle.net/10138/308707

https://doi.org/10.1016/j.seares.2019.101781

cc_by

acceptedVersion

Downloaded from Helda, University of Helsinki institutional repository.

This is an electronic reprint of the original article.

This reprint may differ from the original in pagination and typographic detail.

Please cite the original version. 
This is the AUTHORS' ACCEPTED MANUSCRIPT, for the published article, please see: https://doi.org/10.1016/j.seares.2019.101781

Full citation:

Norkko J, Pilditch CA, Gammal J, Rosenberg R, Enemar A, Magnusson M, Granberg ME, Lindgren JF, Agrenius S, Norkko A (2019) Ecosystem functioning along gradients of increasing hypoxia and changing soft-sediment community types. Journal of Sea Research 153: 101781

\section{Ecosystem functioning along gradients of increasing hypoxia and changing soft-sediment community types}

Joanna Norkkoa,*, Conrad A. Pilditchb, Johanna Gammala, Rutger Rosenbergc, Arvid Enemarc, Marina Magnussond, Maria E. Granberge, J. Fredrik Lindgrenf, Stefan Agreniusg, Alf Norkkoa,h

a Tvärminne Zoological Station, University of Helsinki, 10900 Hanko, Finland

b School of Science, University of Waikato, Private Bag 3105, Hamilton, New Zealand.

c Department of Biological and Environmental Sciences - Kristineberg, University of Gothenburg, Kristineberg 566, 45178 Fiskebäckskil, Sweden

d Marine Monitoring AB, Strandvägen 9, 45330 Lysekil, Sweden

e IVL Swedish Environmental Research Institute, Kristineberg Marine Research and Innovation Center, Kristineberg 566, 45178 Fiskebäckskil, Sweden

f Department of Mechanics and Maritime Sciences, Chalmers University of Technology, 41296 Gothenburg, Sweden

g Department of Marine Sciences - Kristineberg, University of Gothenburg, Kristineberg 566, 45178 Fiskebäckskil, Sweden

h Baltic Sea Centre, Stockholm University, 10691 Stockholm, Sweden

* Corresponding author, joanna.norkko@helsinki.fi 
Declarations of interest: None.

Author contributions: JN, AN, JG, RR designed the study.

JN, CP, JG, RR, AE, MM, MG, AN conducted the field sampling.

JG, RR, AE, SA analysed the macrofauna samples.

FL analysed the meiofauna samples.

$\mathrm{RR}, \mathrm{MM}$ analysed the sediment profile image data.

$\mathrm{CP}, \mathrm{JG}, \mathrm{AN}, \mathrm{FL}$ conducted the statistical analyses.

JN drafted the manuscript and all authors contributed.

All authors have approved the final article.

Keywords. Hypoxia; nutrient cycling; structural community changes; ecosystem functioning; macrofauna; meiofauna

\section{Highlights}

1. Hypoxia decimates macrofauna, but fauna can still contribute to nutrient cycling

2. Meiofauna is less sensitive to hypoxia compared with macrofauna

3. The link between community structure and ecosystem function is mediated by context 
1 Abstract. Marine ecosystems world-wide are threatened by oxygen deficiency, with potential

2 serious consequences for ecosystem functioning and the goods and services they provide. While the

3 effects of hypoxia on benthic species diversity are well documented, the effects on ecosystem

4 function have only rarely been assessed in real-world settings. To better understand the links

5 between structural changes in macro- and meiofaunal communities, hypoxic stress and benthic

6 ecosystem function (benthic nutrient fluxes, community metabolism), we sampled a total of 11 sites

7 in Havstensfjord and Askeröfjord (Swedish west coast) in late summer, coinciding with the largest extent and severity of seasonal hypoxia in the area. The sites spanned oxic to anoxic bottom water,

9 and a corresponding gradient in faunal diversity. Intact sediment cores were incubated to measure

10 fluxes of oxygen and nutrients $\left(\mathrm{NO}_{3}, \mathrm{NO}_{2-}, \mathrm{NH}_{4+}, \mathrm{PO}_{43-}, \mathrm{SiO}_{4}\right)$ across the sediment-water interface.

11 Sediment profile imaging (SPI) footage was obtained from all sites to assess structural elements and 12 the bioturbation depth, and additional samples were collected to characterise sediment properties 13 and macro- and meiofaunal community composition. Bottom-water $\mathrm{O}_{2}$ concentration was the main 14 driver of macrofauna communities, with highest abundance and biomass, as well as variability, at 15 the sites with intermediate $\mathrm{O}_{2}$ concentration. Meiofauna on the other hand was less sensitive to 16 bottom-water $\mathrm{O}_{2}$ concentration. Oxygen was the main driver of nutrient fluxes too, but macrofauna 17 as well meiofauna were also significant predictors; DistLM analyses indicated that $\mathrm{O}_{2}$ concentration, macrofaunal abundance or biomass, and meiofaunal abundance collectively explained $63 \%, 30 \%$ and $28 \%$ of the variation in sediment $\mathrm{O}_{2}$ consumption, $\mathrm{NH}_{4}+$ flux and $\mathrm{PO}_{43}-$ flux, respectively. The study provides a step towards a more realistic understanding of the link between benthic fauna and ecosystem functioning, and the influence of disturbance on this relationship, which is important for management decisions aimed at protecting the dwindling biodiversity in the coastal zones around the world. 
Hypoxia, benthic fauna and nutrient cycling

\section{INTRODUCTION}

Marine ecosystems worldwide are threatened by oxygen deficiency, with potential serious consequences for ecosystem functioning and the goods and services these ecosystems provide (Diaz and Rosenberg 2008, Rabalais et al. 2014). While eutrophication and organic enrichment are the main anthropogenic causes of hypoxia, the warming climate will further exacerbate the deoxygenation of the oceans (Breitburg et al. 2018). This highlights the urgency of better understanding how ecosystem functioning might change with increasing hypoxia, and what factors and mechanisms are driving these changes.

The deleterious effects of increasing hypoxia on soft-sediment macrofaunal communities are well documented, with a general decrease of large, deeper-dwelling animals and an increase of smaller, fast-growing species, until anoxia decimates all macrofauna (Pearson and Rosenberg 1978, Diaz and Rosenberg 1995, Gray et al. 2002, Levin et al. 2009). Through their bioturbation and bioirrigation activities, macrofauna enhance oxygen penetration into the sediments influencing all oxygen-dependent processes in the sediment, including organic matter mineralization through stimulation of microbial activity, and nutrient cycling (Levinton 1995, Aller and Aller 1998, Meysman et al. 2006, Glud 2008). These activities are reduced under hypoxic conditions due to changes in the behaviour and diversity of macrofauna. Bottom-water $\mathrm{O}_{2}$ concentrations also influence biogeochemical processes at the sediment-water interface affecting nutrient concentrations and speciation in the water column. In particular, the release of phosphate and ammonium is enhanced under hypoxic conditions (Mortimer 1941, Ingall et al. 1993, Cowan and Boynton 1996, Slomp et al. 2002, McCarthy et al. 2008, Reed et al. 2011, Jäntti and Hietanen 2012). Nevertheless, the step from documenting structural changes in faunal composition due to hypoxia to understanding the impact on ecosystem functions (e.g., nutrient cycling) is long and we have only recently begun to assess the interacting direct (e.g. chemical release of nutrients from the 
Hypoxia, benthic fauna and nutrient cycling

51 sediment) and indirect (e.g. via effects on macrofauna) effects of hypoxia on ecosystem function in natural settings (Norkko et al. 2015, Gammal et al. 2017).

The effects of hypoxia on benthic ecosystem functioning are likely to be highly context dependent, posing further challenges to building a general understanding of the effects and predicting future changes. Impacts will depend on the temporal and spatial scales of hypoxia (a function of mixing and water exchange), the type of habitat (e.g. muddy, sandy) and faunal diversity. Places with high species diversity are generally expected to tolerate stress better than low-diversity systems (insurance hypothesis, e.g., Yachi and Loreau 1999), but it is important to consider biodiversity as a much wider concept than just the number of species, including aspects such as species identity and dominance patterns. For example, dominance by one or a few species with particular functional traits may be more important than species diversity per se for some aspect of ecosystem functioning (Chapin III et al. 1997). A dominant species with a good hypoxia tolerance may thus maintain a vital process, e.g. bioturbation, when conditions deteriorate (Norkko et al. 2015, Rakocinski and Menke 2016)). Thus, species identity and the prevalence of functionally important traits will be important for assessing hypoxia-induced changes in ecosystem functioning.

It is difficult to directly link disturbance-induced community changes to quantifiable shifts in functioning without empirical measurements. Nevertheless, some assumptions can be made. Under anoxic conditions, when the macrofauna has been lost, there is no effect of the fauna on nutrient cycling and therefore chemical reactions, modulated by microbes, dominate solute fluxes and ecosystem function. As conditions deteriorate from normoxia, the ensuing hypoxia results in different community types, representing different successional stages (Pearson and Rosenberg 1978, Diaz and Rosenberg 1995, Nilsson and Rosenberg 1997, Rosenberg et al. 2002). Sustained hypoxia decimates big individuals, e.g., large deep-burrowing bivalves, which are particularly 
important for nutrient cycling (Norkko et al. 2013). Thus, the macrofaunal influence on nutrient cycling is likely to be reduced in a decimated community, with lower species diversity, abundance and biomass. In addition, already at sub-lethal levels of hypoxic stress, behavioural and physiological changes may affect the species' contribution to processes such as bioturbation, but species-specific sensitivities to hypoxia vary greatly (Vaquer-Sunyer and Duarte 2008). Thus, hypoxia results in a non-random species loss and the remaining community types may be adapted to low-oxygen environments. It is, however, unclear how well they perform.

Much of our understanding of biodiversity-ecosystem functioning (BEF) relationships stems from mechanistic, small-scale laboratory studies with only a few species and limited regard of changing environmental conditions, such as increasing hypoxia (Snelgrove et al. 2014). While the potential indirect effects of hypoxia via fauna on biogeochemical processes have been indicated in several high-profile papers (e.g., Levin et al. 2009, Middelburg and Levin 2009, Friedrich et al. 2014), actual measurements still appear to be virtually non-existent. To our knowledge, the effects of hypoxia on BEF in terms of nutrient cycling have not been empirically tested in a meaningful way in the laboratory or under natural field conditions. While it is challenging to assign causality in field studies, relevant field measurements involving natural communities in a range of different environments and geographical areas are imperative for developing a realistic understanding of the effects of disturbance on BEF relationships. Using correlative field surveys and incubations of nonmanipulated sediment cores for measurement of benthic nutrient fluxes in a range of contrasting environments, we have started to understand the importance of benthic macrofauna for nutrient cycling and the concurrent effects of increasing hypoxia. This body of work includes a large-scale study across the entire open Baltic Sea, spanning a salinity and corresponding diversity gradient as well as areas that are more or less permanently hypoxic (Norkko et al. 2015) and a coastal study in a brackish, seasonally hypoxic, low-diversity system in the northern Baltic Sea (Gammal et al. 
Hypoxia, benthic fauna and nutrient cycling

101 2017). In order to pinpoint the mechanisms involved, the same research team has conducted coastal

102 field experiments where hypoxic events of different intensity were simulated in situ and the

103 responses assessed (Villnäs et al. 2012, Norkko et al. 2013, Villnäs et al. 2013). In all of these

104 studies, macrofauna was important for explaining the variability in nutrient fluxes across the

105 sediment-water interfaces, but this effect decreased as oxygen conditions deteriorated. It is now

106 imperative to investigate whether the patterns in higher-diversity systems are comparable to the

107 ones found in the low-diversity Baltic Sea.

108

109 Missing from these studies is also the consideration of several size classes and trophic levels

110 simultaneously, i.e. meiofauna and microbes. It is known that the influence of macrofauna on

111 ecosystem function, sediment biogeochemistry and nutrient cycling, is modulated by meiofauna

112 (Bonaglia et al. 2014, Piot et al. 2014) and by microbes (Yazdani Foshtomi et al. 2015), but studies

113 that examine these relationships in relation to hypoxia and nutrient cycling are rare. Also, the Baltic

114 Sea where our previous studies have been conducted is a low-diversity system (Villnäs and Norkko

115 2011), calling for comparative studies in fully marine systems that experience hypoxia but have

116 higher macrofaunal diversity (and potentially greater redundancy), such as the Swedish west coast.

118 Hypoxic or anoxic dead zones in deeper waters (e.g. the Baltic Sea, the Gulf of Mexico) have been

119 known for decades (e.g., Rabalais et al. 2002, Conley et al. 2009a), but the problem of near-shore, 120 coastal hypoxia is now receiving ever more attention (Conley et al. 2011). The coastal ecosystems

121 are heterogeneous and diverse, with enclosed inlets, and steep gradients in physical, chemical and

122 biological properties. They are hotspots of diversity and productivity, but at the same time human

123 impacts are very pronounced along the coasts (Levin et al. 2001, Halpern et al. 2008), highlighting

124 the need for management actions based on sound understanding of the links between hypoxic

125 disturbance and the functioning of these systems. 
Hypoxia, benthic fauna and nutrient cycling

127 To investigate the links between benthic communities, hypoxic stress and nutrient fluxes across the 128 sediment-water interface, we conducted a field study in the seasonally hypoxic Havstensfjord and 129 Askeröfjord (Swedish west coast), at sites covering a gradient from oxic to anoxic bottom water, 130 with a corresponding gradient in diversity. The aim was to assess how macrofauna and meiofauna 131 communities change with increasing hypoxia and whether the effects of these changes on nutrient 132 cycling/fluxes could be quantified. We also investigated whether the different community types, or 133 successional stages, corresponded to different levels of sediment oxygen consumption (a proxy for 134 community metabolism). Given the higher species diversity and thus potentially higher functional 135 redundancy in Havstensfjord and Askeröfjord compared to our previous studies in the Baltic Sea 136 (Norkko et al. 2015, Gammal et al. 2017), we anticipated that the effect of hypoxia on the faunal 137 contribution to functioning would be smaller.

\section{MATERIAL AND METHODS}

\section{Study area, sampling and sample processing}

141 The Havstensfjord is a narrow fjord on the Swedish west coast and part of the Orust fjord system 142 (Fig. 1). The fjord extends about $25 \mathrm{~km}$ from north to south with its main connection to the sea 143 further south through Askeröfjord. The fjord system has been monitored since the 1950s and 144 bottom-water oxygen concentrations have steadily declined since then (Nilsson and Rosenberg 145 1997). The fjords suffer from seasonal hypoxia and particularly in the northern parts, deeper waters 146 may be anoxic for extended periods of the year (Hansson et al. 2013). The deeper parts of

147 Havstensfjord are usually ventilated once per year in late winter or early spring. The periods of 148 lower oxygen concentrations also correspond to higher concentrations of phosphate and ammonium 149 in the bottom waterers (Fig. 1). 
151 During the peak of seasonal hypoxia, in early September 2011 we sampled 9 sites in the

152 Havstensfjord and 2 outside the entrance in the Askeröfjord, covering a gradient from oxic sites

153 outside the sill to Havstensfjord to hypoxic sites inside the sill, and then almost anoxic bottom water

154 at the deepest site in the north (Fig. 1, Table 1). Although long-term monitoring data does not exist

155 for all 11 sites, bottom-water oxygen concentrations in the fjord are strongly related to depth and

156 therefore the assumption is that all sites follow a general pattern of lowest oxygen conditions at the

157 end of summer. The choice of sampling sites was based on Nilsson and Rosenberg (1997) and the

158 sampling was conducted on-board $R / V$ Skagerak. All sites had muddy sediments, similar organic

159 content and were 23-39 m deep.

160
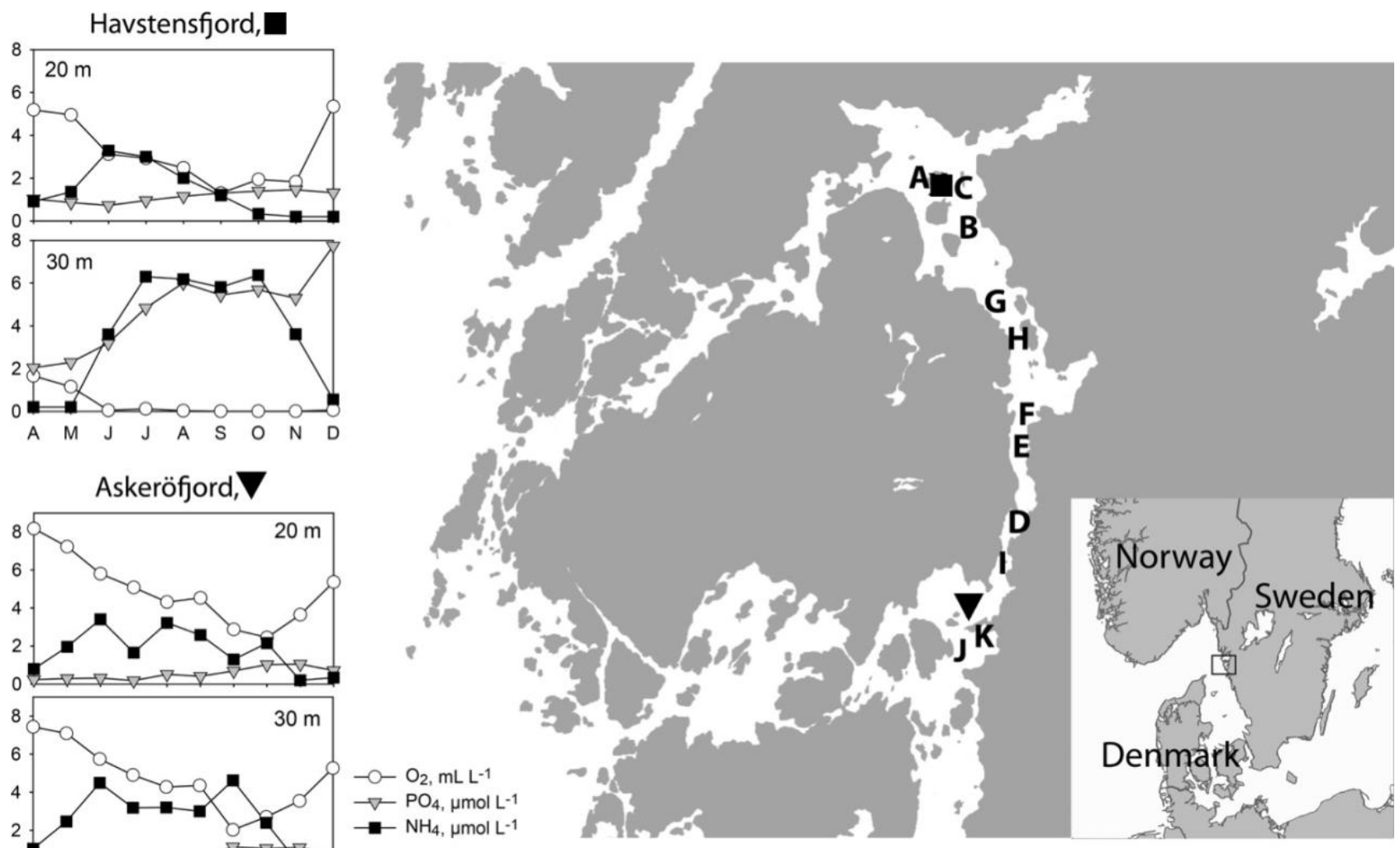

163 Figure 1. Map of the sampling area in the Orust fjord system on the Swedish west coast. Letters A-

164 K indicate sites sampled during this study in September 2011. Inserted graphs present

165 concentrations of oxygen $\left(\mathrm{O}_{2}, \mathrm{~mL} \mathrm{~L}-1\right)$, phosphate $\left(\mathrm{PO}_{43-}, \mu \mathrm{mol} \mathrm{L-1}\right)$, and ammonium $\left(\mathrm{NH}_{4+}, \mu \mathrm{mol}\right.$ 
166 L-1) measured at 20 and $30 \mathrm{~m}$ depth at monitoring sites in Havstensfjord (filled square; station name 167 Havstensfjord) and Askeröfjord (filled triangle; station name Galterö) from March or April to 168 December 2011, as part of the national Swedish coastal monitoring program (data obtained from the SMHI database SHARKweb).

171 To characterise environmental conditions at each site, bottom-water salinity and temperature were 172 determined from CTD casts (Sea-Bird). Intact sediment cores were collected with a Gemax 173 twincorer $(\mathrm{ID}=90 \mathrm{~mm})$ and the surface sediment $(0-1 \mathrm{~cm})$ analysed for organic content $(\mathrm{OC}, \%$ 174 loss on ignition, $3 \mathrm{~h}$ at $\left.500^{\circ} \mathrm{C}\right)$ and sediment silt/clay content $(\%<63 \mu \mathrm{m}$, determined by wet sieving). To illustrate differences in the sedimentary environment between anoxic, hypoxic and oxic sites, four sediment profile images (SPI) were obtained from each site and digitally analysed in PhotoShop for sediment surface/subsurface structures and mean depth of the apparent redox potential discontinuity (aRPD). Based on these variables a benthic habitat quality (BHQ) index was calculated (see details in Nilsson and Rosenberg 1997).

Oxygen and nutrient fluxes across the sediment-water interface were estimated by on-board 182 incubation of undisturbed, intact sediment cores ( $n=5$ per site). The upper parts of Gemax split 183 tubes were sealed and used as flux chambers (30 cm sediment $+10 \mathrm{~cm}$ bottom water). The core lid contained a Teflon-coated magnetic stirring bar, which provided continuous gentle stirring by an external magnet. Core incubations (in the dark at $11^{\circ} \mathrm{C}$ ) started immediately after collection and water samples for $\mathrm{O}_{2}$ and nutrient concentrations ( $\left.\mathrm{NO}_{3-}, \mathrm{NO}_{2-}, \mathrm{NH}_{4+}, \mathrm{PO}_{43-}, \mathrm{SiO}_{4}\right)$ were obtained at 187 the start and the end of incubation (4 $\mathrm{h}$ later). The differences in concentration were used to 188 calculate solute fluxes ( $\mu \mathrm{mol} \mathrm{m-2} \mathrm{d-1).} \mathrm{At} \mathrm{the} \mathrm{end} \mathrm{of} \mathrm{incubation,} \mathrm{all} \mathrm{cores} \mathrm{were} \mathrm{sieved} \mathrm{to} \mathrm{quantify}$ 189 benthic macrofaunal species richness, abundance and biomass $(0.5 \mathrm{~mm}$ sieve, preserved in $70 \%$ 190 ethanol, biomass estimated as blotted wwt). Dissolved oxygen was determined by Winkler titration, 191 while the nutrient samples were filtered (GF/F) and then frozen $\left(-20^{\circ} \mathrm{C}\right)$ until analysed 192 spectrophotometrically with an autoanalyser (Lachat QuickChem 8000). 
Hypoxia, benthic fauna and nutrient cycling

194 To provide an additional and more robust estimate of benthic macrofaunal species richness, abundance and biomass, than that gained from the small flux cores $(0.006 \mathrm{~m} 2)$, we also sampled with a Smith-McIntyre grab $(0.1 \mathrm{~m} 2,3$ replicates per site, $1 \mathrm{~mm}$ sieve, preserved in $70 \%$ ethanol).

From a grab sample at each site, three subsamples ( $40 \mathrm{~g} \mathrm{wwt}$ ) of the top $2 \mathrm{~cm}$ sediment were taken for analyses of meiofauna community composition. These samples were stored in an ethanol:glycerol (95:5\%) solution and meiofauna extracted using Ludox (Burgess 2001). Sediment was rinsed with tap water on a $63 \mu \mathrm{m}$ sieve to remove ethanol, salt and organic matter. Remaining sediment was transferred to a 13-ml centrifuge tube, centrifuged at $800 \mathrm{G}$ for 5 minutes and the water was decanted. $10 \mathrm{ml}$ of Ludox AS-40 was added to the tube and the tube was then vortexed at $1800 \mathrm{rpm}$ for $30 \mathrm{~s}$ and then at $1400 \mathrm{rpm}$ for $4.5 \mathrm{~min}$. Afterwards the sample was centrifuged at 800 $\mathrm{G}$ for 5 minutes and approximately $2 \mathrm{ml}$ of the top sample was transferred to a new tube. The old tube was topped up with fresh Ludox and the procedure was repeated. The retained material was sieved with milliQ water through a $63-\mu \mathrm{m}$ sieve to remove the Ludox from the extracted meiofauna and preserved in ethanol:glycerol solution. The extracted meiofauna were put on petri dishes and diluted with milliQ water. The petri dishes were then digitally scanned on an Epson Perfection v500 210 (6400 dpi, 16-bit grey scale in positive film mode). The meiofauna were analysed using the image 211 analysis software ZooImage (Lindgren et al. 2013) to the following major taxonomic groups:

212 Nematoda, Harpacticoida, Rotaliina, Reophax, Allogromiina, Nonionella, Tanaidacea, Polychaeta 213 and Ostracoda.

\section{Statistical analyses}

216 Multivariate analyses in PRIMER 6 (Clarke and Gorley 2006) based on taxon abundance was used 217 to assess inter-site variations in faunal community composition. Macrofauna community data from 
Hypoxia, benthic fauna and nutrient cycling

218 grab samples were transformed (square root) to lessen the influence of dominant taxa before Bray-

219 Curtis similarity calculations. Meiofauna data were not transformed because of the relatively coarse

220 taxonomic resolution and even distribution of taxa. Resulting linkages were visualised in a multi-

221 dimensional scaling (MDS) plot based on replicate data from which site clusters were identified.

222 The statistical validity of the site clusters $(p<0.05)$ was tested using the similarity profile test

223 (SIMPROF; Clarke 1993).

225 We used a correlation-based principal components analysis (PCA) to identify environmental 226 variables (Table 1) responsible for differences among sites. The analysis was conducted on 227 normalised environmental parameters (site average) using Euclidean distance to generate the 228 resemblance matrix. The purpose of this analysis was to identify a reduced set of independent 229 environmental predictors that could be used to explain variation in faunal composition and 230 ecosystem function (here focussing on sediment oxygen consumption (SOC) and nutrient 231 regeneration $\left(\mathrm{NH}_{4}+\right.$ and $\mathrm{PO}_{43}$ - flux $)$ ).

233 The correlation between the site-averaged multivariate assemblage composition (grab samples) and 234 environmental variables was examined using distance based linear models (DistLMs) in 235 PERMANOVA+ (Anderson et al. 2008). The same approach was used for measures of ecosystem 236 function except similarity matrices were based on Euclidean distance rather than Bray-Curtis 237 similarity and we also included univariate measures of macrofaunal community composition 238 (abundance, diversity and biomass from flux cores) to assess their contribution to ecosystem 239 function. Because we had macrofaunal composition from each core, solute flux data was not site240 averaged prior to analysis. Site A was omitted from the DistLM analyses because it was almost 241 anoxic, contained no macrofauna and nutrient fluxes were much larger than the remaining 242 hypoxic/oxic sites (see results). The only exception to this was the analysis involving the 
Hypoxia, benthic fauna and nutrient cycling

243 relationship between meiofauna community structure and environmental variables as meiofauna

244 were present at Site A. Although DistLM is a semi-parametric, permutation-based method that does

245 not rely on normally distributed data, we checked the normality of the environmental data with

246 Shapiro-Wilks tests and no transformations were necessary. We first performed marginal tests to

247 identify strong, significant predictors, irrespective of other variables, then partial tests to assess the

248 explanatory value of a predictor variable after all other significant predictors had been accounted

249 for. Finally, DistLMs were run using the step-wise selection procedure and $\mathrm{r} 2$ selection criterion to

250 identify the (linear) combinations of significant predictor variables that explained the greatest

251 proportion of variation. $P$ values were obtained for predictor variables by 9999 permutations. 
258
Table 1. Environmental variables at the study sites in the Havstensfjord and Askeröfjord, sampled in September 2011. Depth, bottom-water temperature, salinity and oxygen concentration, surface sediment $(0-1 \mathrm{~cm})$ silt/clay and organic content (OC), and depth of the apparent redox potential discontinuity layer (aRPD; from SPI analyses). These factors were included in the PCA analysis. In addition, the benthic habitat quality (BHQ), the corresponding BHQ stage and site groupings based on macrofaunal abundance (see Table 2) are listed.

\begin{tabular}{|c|c|c|c|c|c|c|c|c|c|c|c|c|}
\hline Site & Longitude & Latitude & $\begin{array}{l}\text { Depth } \\
\text { (m) }\end{array}$ & $\begin{array}{l}\text { Temp } \\
\left({ }^{\circ} \mathrm{C}\right)\end{array}$ & Salinity & $\begin{array}{c}\mathrm{O}_{2} \\
(\mathrm{ml} \mathrm{L}-1)\end{array}$ & $\begin{array}{l}\text { Silt/clay } \\
(\%)\end{array}$ & $\begin{array}{l}\mathrm{OC} \\
(\%)\end{array}$ & $\begin{array}{l}\text { aRPD } \\
(\mathrm{cm})\end{array}$ & BHQ & $\begin{array}{l}\text { BHQ } \\
\text { stage }\end{array}$ & $\begin{array}{l}\text { Macrofaunal } \\
\text { group }\end{array}$ \\
\hline $\mathrm{A}$ & 58.31482 & 11.77350 & 39.1 & 6.8 & 32.2 & 0.11 & 66.7 & 9.9 & 0.1 & 1.50 & 0 & \\
\hline $\mathrm{B}$ & 58.29382 & 11.80400 & 26.3 & 10.6 & 31.0 & 0.89 & 95.0 & 10.4 & 0.3 & 5.00 & 2 & 1 \\
\hline $\mathrm{C}$ & 58.31382 & 11.80182 & 27.0 & 8.5 & 31.5 & 0.99 & 82.4 & 7.9 & 0.2 & 6.75 & 2 & 1 \\
\hline $\mathrm{D}$ & 58.16616 & 11.85200 & 24.2 & 11.3 & 29.4 & 1.02 & 73.7 & 9.8 & 1.7 & 7.50 & 2 & 2 \\
\hline $\mathrm{E}$ & 58.19532 & 11.85000 & 27.5 & 11.0 & 30.0 & 1.20 & 70.7 & 9.1 & 3.7 & 10.75 & 3 & 3 \\
\hline $\mathrm{F}$ & 58.20620 & 11.85116 & 25.8 & 10.4 & 30.1 & 1.23 & 77.7 & 8.8 & 2.7 & 10.25 & 3 & 3 \\
\hline $\mathrm{G}$ & 58.26146 & 11.80730 & 25.6 & 10.2 & 30.6 & 1.28 & 80.7 & 12.0 & 3.2 & 10.25 & 3 & 3 \\
\hline $\mathrm{H}$ & 58.23506 & 11.84782 & 25.2 & 10.4 & 30.4 & 1.34 & 82.4 & 9.4 & 2.3 & 10.75 & 3 & 2 \\
\hline I & 58.14816 & 11.84116 & 26.9 & 12.4 & 29.8 & 1.36 & 85.1 & 8.6 & 2.3 & 10.50 & 3 & 4 \\
\hline $\mathrm{J}$ & 58.11682 & 11.83050 & 26.7 & 13.8 & 28.6 & 2.11 & 82.9 & 7.7 & 0.7 & 7.00 & 2 & 4 \\
\hline $\mathrm{K}$ & 58.11250 & 11.81950 & 23.2 & 15.1 & 25.1 & 2.91 & 78.6 & 8.4 & 0.7 & 7.25 & 2 & 4 \\
\hline
\end{tabular}


Hypoxia, benthic fauna and nutrient cycling

260

261

262

263

264

265

266

\section{RESULTS}

\section{Environmental variables}

All sites had muddy sediments with a silt/clay content $>67 \%$ and OC between 8 and 12\% (Table 1). Bottom-water temperature varied between $7^{\circ} \mathrm{C}$ at the deepest site and $15^{\circ} \mathrm{C}$ at the shallowest site. Corresponding values for salinity and $\mathrm{O}_{2}$ concentrations were 32 and 25 , and 0.1 and $2.9 \mathrm{ml} \mathrm{L}-1$, respectively. Thus, even at the shallowest site, the $\mathrm{O}_{2}$ concentration was relatively low at the time of sampling, although all sites except the innermost sites (A, B, C) likely experience relatively good $\mathrm{O}_{2}$ conditions during the rest of the year (Fig. 1). The 2-dimensional PCA ordination of the environmental variables (Table 1) accounted for a large fraction (72\%) of the total variance and revealed sites primarily dispersed across two gradients (Fig. 2, PCA analysis). PCA1 alone accounted for $52 \%$ of the variance and was most strongly correlated $(|r|=0.5-0.6)$ with temperature, salinity and bottom-water $\mathrm{O}_{2}$ concentration and to a lesser extent depth $(r=0.4)$. PCA2 accounted for only $20 \%$ of the inter-site variation and was driven by differences in the aRPD depth and OC ( $r=0.7$ and 0.5 , respectively). Salinity and temperature were strongly correlated with oxygen concentration $(|r|>0.9, p<0.001)$, consequently we used a reduced set of weakly correlated $(|r|<0.6)$ environmental variables (depth, $\mathrm{O}_{2}$ concentration, OC, silt/clay, aRPD depth) in subsequent DistLM analyses. Variables excluded because of co-correlation explained less of the variation in response measures than the variables retained.

.

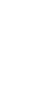

(

(

2

.

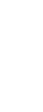




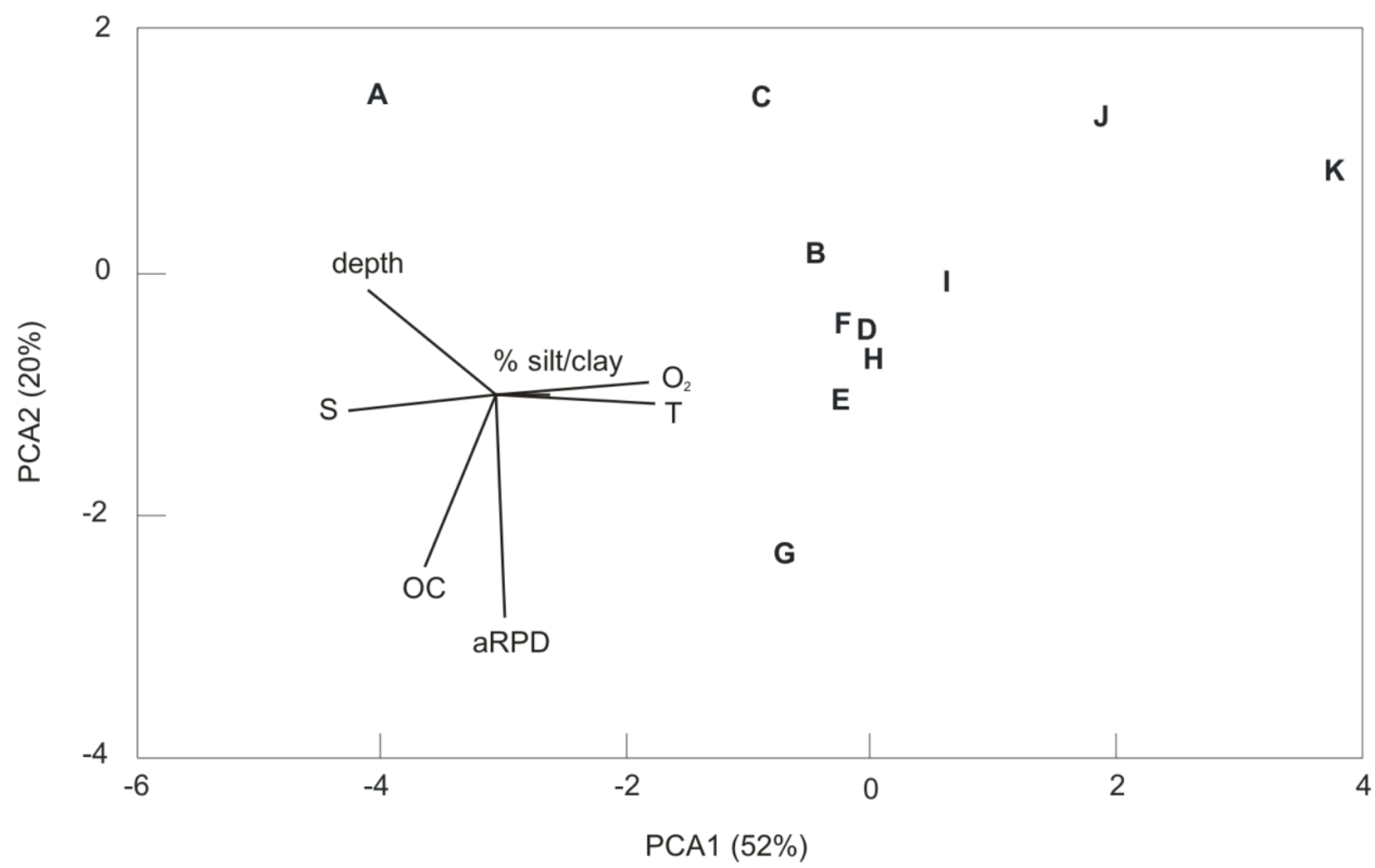

Figure 2. A two-dimensional ordination of a principal components analysis of site environmental variables, which collectively explained $72 \%$ of the variation between sites. Also shown is the correlation between the component axes and the environmental variables.

Sediment Profile Images. The $\mathrm{O}_{2}$ gradient was also visible in the sediment profile images, with clear differences between sites with different near-bottom $\mathrm{O}_{2}$ concentrations, here exemplified by images from almost anoxic (site A), hypoxic (sites C, E, G, H) and oxic areas (site I; Fig. 3). At the almost anoxic site A, the whole sediment was reduced and large amounts of fecal pellets were seen at the sediment surface. The image from site $\mathrm{C}$, at about $1 \mathrm{ml} \mathrm{L}-1$ of near-bottom $\mathrm{O}_{2}$ concentration, showed no bioturbation activity and a reduced sediment with a marginally oxidised sediment surface, but several small tubes were at the surface. These tubes are most likely inhabited by spionids. BHQ was 5. Site E had an anthozoan, Virgularia mirabilis, at the well bioturbated sediment surface and several vertical burrows. A feeding void was present at a depth between 8 and $10 \mathrm{~cm}$. The mean aRPD was $2.6 \mathrm{~cm}$ and the BHQ index was 10 . Site $\mathrm{G}$ demonstrated great

301 bioturbation activity at the sediment surface with some protruding tubes and several oxic burrows 
302 going down into the surrounding reduced sediment. Some vertical black patches could indicate

303 presence of dead animals. The mean aRPD was $2.0 \mathrm{~cm}$ and the BHQ index was 9. Similarly, site H

304 had an ophiuroid at the sediment surface and great bioturbation activity. Many vertical tubes were

305 stretching down to several centimetres in the sediment surrounded by reduced sediment. Mean

306 depth of the aRPD was $2.8 \mathrm{~cm}$ and the BHQ index was 11. The image from site I showed some

307 tubes at the sediment surface and some vertical oxidised burrows, where infauna is visible in one

308 burrow. The sediment surface showed signs of great bioturbation activity, and the mean depth of the

309 aRPD was $3.1 \mathrm{~cm}$ and the BHQ index was 12.
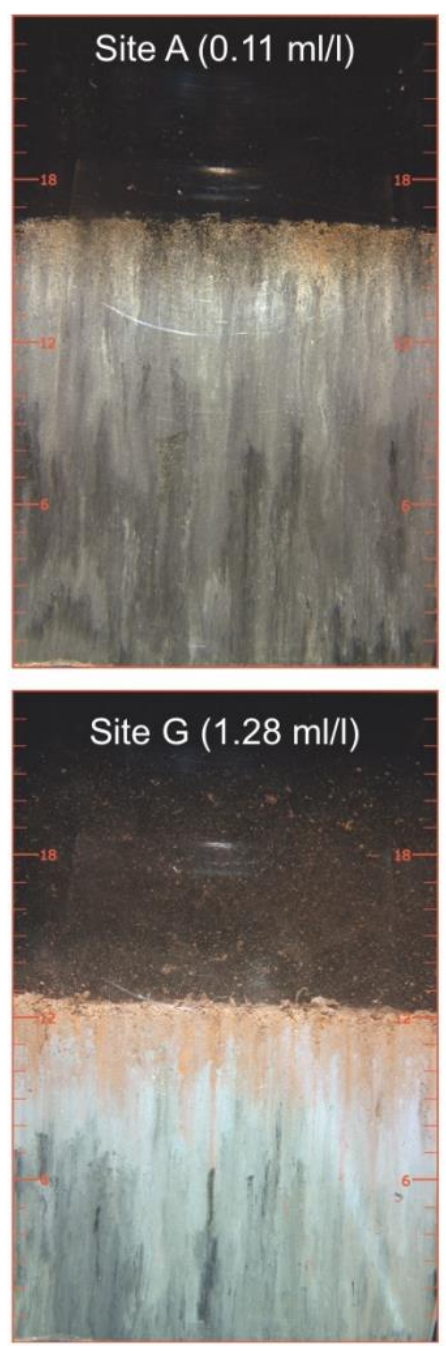
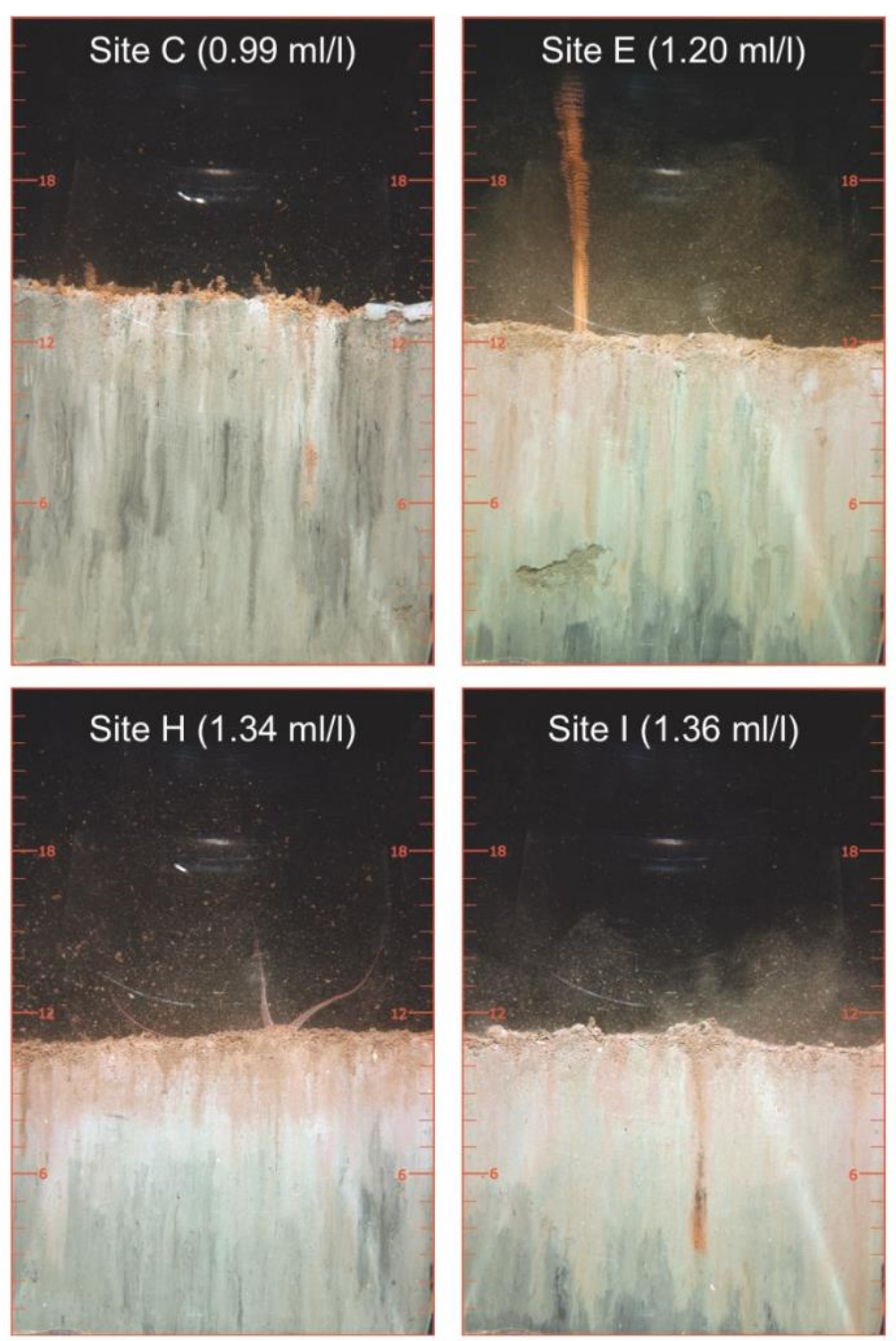
311 Figure 3. Selected sediment profile images with overlaying water from sites with different bottom312 water $\mathrm{O}_{2}$ concentrations. The colours have been digitally enhanced to facilitate interpretation. The 313 vertical scale is in centimetres.

Macrofauna. In general, macrofauna species richness, abundance and biomass was greatly reduced at the sampling sites with bottom-water $\mathrm{O}_{2}$ concentrations $<1.3 \mathrm{ml} \mathrm{L-1}$, while the highest abundance and biomass, and variability, was observed at the sites with intermediate $\mathrm{O}_{2}$ concentration (Fig. 4). Multivariate analyses of macrofaunal abundance revealed four distinctive site clusters (confirmed by SIMPROF $p<0.05$ ) that separated at 50-65\% similarity (Fig. 5a). These groupings reflected changes in macrofaunal assemblage structure associated with the gradient in $\mathrm{O}_{2}$ concentration (Table 1): severely hypoxic (0.9-1.0 ml L-1, sites B, C), two hypoxic groups (1.0-1.3 ml L-1, sites E, F, G and sites D, H), and oxic (1.4-2.9 ml L-1, sites I, J, K). The dissimilarity between the oxic and the two hypoxic groups was approximately the same, likely driven by other co-varying spatial or environmental factors, which cannot be determined this from this dataset. The almost anoxic site A (0.1 ml L-1) had no macrofauna and was excluded from this analysis. Among dominants in the hypoxic as well as oxic areas were the surface deposit-feeding bivalve Abra nitida, the chemosymbiotic bivalve Thyasira flexuosa (which can also suspension feed), the sub-surface deposit-feeding polychaete Scalibragma inflatum and the facultative suspension-feeding and surface deposit-feeding brittle star Amphiura filiformis, indicating a high level of tolerance to low $\mathrm{O}_{2}$ concentrations in these species (Table 2). Thyasira flexuosa was additionally dominant even in the severely hypoxic areas. Conspicuous species in severe hypoxia were the tube building polychaetes Maldane sarsi and Polydora caulleryi, which have minor effects on the depth of the aRPD, the polychaete Chaetozone setosa, and the burrowing bivalve Thyasira flexuosa. Total abundance as well as total biomass decreased from the oxic to the severely hypoxic groups (Table 2). Notable is that that the suspension-feeding bivalve Arctica islandica dominated the biomass, with only a few large individuals, at sites in the two hypoxic clusters (sites D, E, F, G). 
Hypoxia, benthic fauna and nutrient cycling

339 In marginal tests multivariate macrofaunal assemblage structure (abundance) was most strongly

340 correlated with aRPD depth followed by silt/clay and $\mathrm{O}_{2}$ concentration (Table 3 ). The other

341 variables (depth, OC) were not significantly correlated $(p>0.2)$. After correcting for the effect of

342 the other variables (i.e. in partial tests), aRPD depth, silt/clay as well as $\mathrm{O}_{2}$ concentration remained

343 significant predictors and in linear combination collectively accounted for $60 \%$ of the variation in 344 assemblage structure. 
Hypoxia, benthic fauna and nutrient cycling
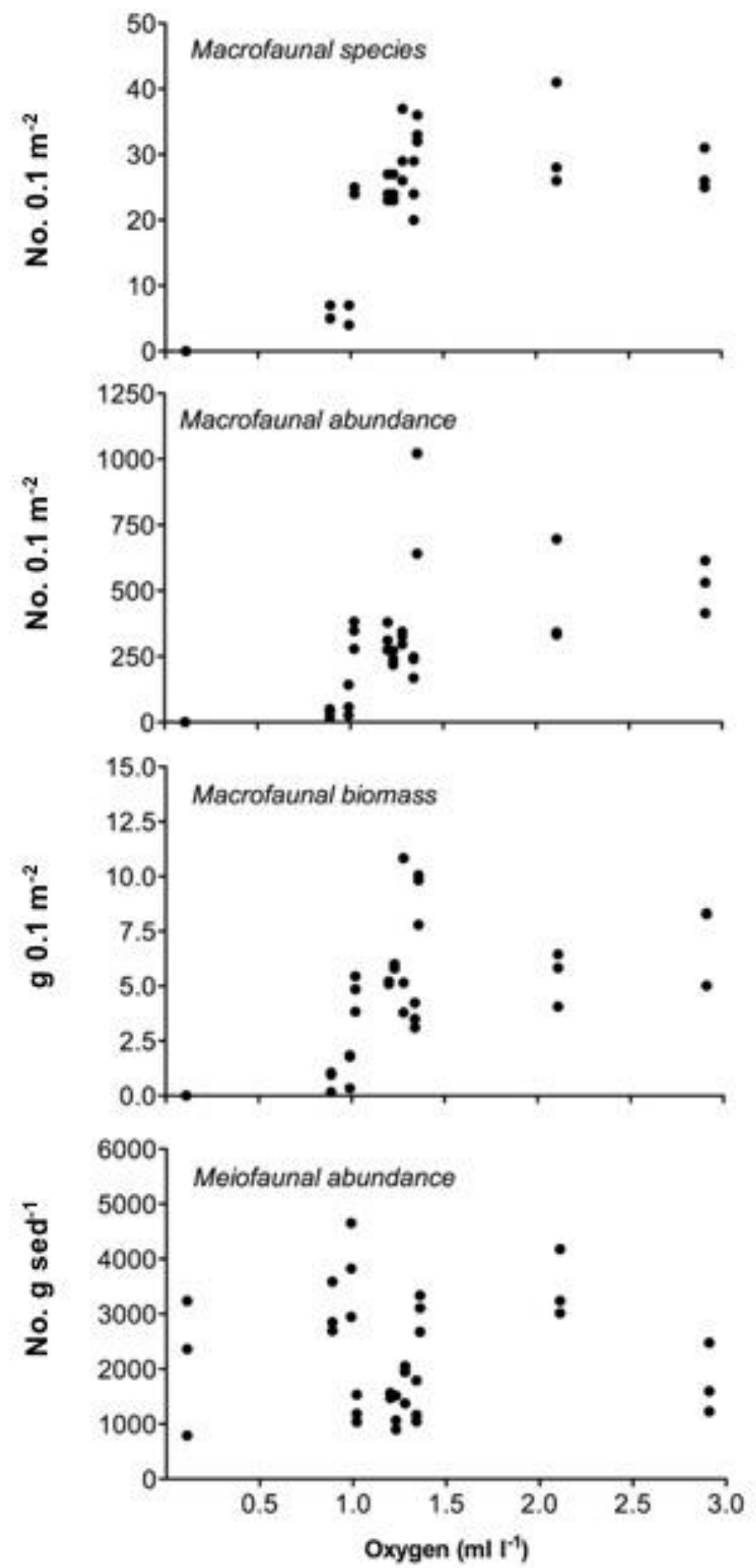

346 Figure 4. Macrofauna species richness, abundance and biomass (per Smith-McIntyre grab, $0.1 \mathrm{~m} 2$ ), 347 and meiofauna abundance (per gram sediment) as a function of bottom-water $\mathrm{O}_{2}$ concentration at 348 the sampling sites. 
351 Table 2. Abundance and biomass (per $0.1 \mathrm{~m} 2$ ) of macrofaunal dominant taxa and community groupings identified as statistically distinctive site clusters using SIMPROF (based on abundance data, Fig. 5). The large bivalve Arctica islandica was excluded from the SIMPROF analysis, but dominated biomass, with only a few large individuals, at sites in the two hypoxic groups.

\begin{tabular}{|c|c|c|c|c|}
\hline Macrofaunal groupings & $\begin{array}{c}\text { Group } \\
\mathbf{1} \\
\text { Severely } \\
\text { hypoxic }\end{array}$ & $\begin{array}{c}\text { Group } \\
\mathbf{2} \\
\text { Hypoxic }\end{array}$ & $\begin{array}{c}\text { Group } \\
\mathbf{3} \\
\text { Hypoxic }\end{array}$ & $\begin{array}{c}\text { Group } 4 \\
\text { Oxic }\end{array}$ \\
\hline \multicolumn{5}{|l|}{$\begin{array}{l}\text { Abundance of } \\
\text { dominant taxa }\end{array}$} \\
\hline Scalibregma inflatum & & 88 & 52 & 233 \\
\hline Abra nitida & & 22 & 49 & 188 \\
\hline Nucula nitidosa & & 10 & 9 & 61 \\
\hline Thyasira flexuosa & 30 & 63 & 15 & 46 \\
\hline Trochochaeta multisetosa & & & & 17 \\
\hline Amphiura filiformis & & & 91 & 10 \\
\hline Amphiura chiajei & & 4 & 20 & \\
\hline Corbula gibba & & 21 & 9 & \\
\hline Anobothrus gracilis & & & 8 & \\
\hline Chaetozone setosa & 13 & 16 & & \\
\hline Terebellides stroemi & & 6 & & \\
\hline Hyala vitrea & & 8 & & \\
\hline Heteromastus filiformis & & 4 & & \\
\hline Maldane sarsi & 7 & & & \\
\hline Polydora caulleryi & 4 & & & \\
\hline Total & 54 & 242 & 253 & 555 \\
\hline \multicolumn{5}{|l|}{$\begin{array}{l}\text { Biomass of } \\
\text { dominant taxa }\end{array}$} \\
\hline Nucula nitidosa & & 0.1 & & 1.8 \\
\hline Scalibregma inflatum & & 0.6 & 0.3 & 1.5 \\
\hline Ophiura ophiura & & & & 0.9 \\
\hline Abra nitida & & & 0.1 & 0.8 \\
\hline Priapulus caudatus & & & 0.2 & 0.6 \\
\hline Tubulanus polymorphus & & & & 0.4 \\
\hline Leptopentacta elongata & & 1.3 & & 0.2 \\
\hline Amphiura sp. & & & 1.8 & \\
\hline Amphiura filiformis & & & 1.3 & \\
\hline Amphiura chiajei & & & 0.3 & \\
\hline Thyasira flexuosa & 0.6 & 0.2 & & \\
\hline Corbula gibba & & 0.2 & 0.3 & \\
\hline Anobothrus gracilis & & & 0.1 & \\
\hline Glycera alba & & 0.4 & & \\
\hline Tubulanus polymorphus & & 0.1 & & \\
\hline Phyllodoce groenlandica & & 0.1 & & \\
\hline Maldane sarsi & 0.3 & & & \\
\hline Total & 0.9 & 3 & 4.4 & 6.2 \\
\hline
\end{tabular}



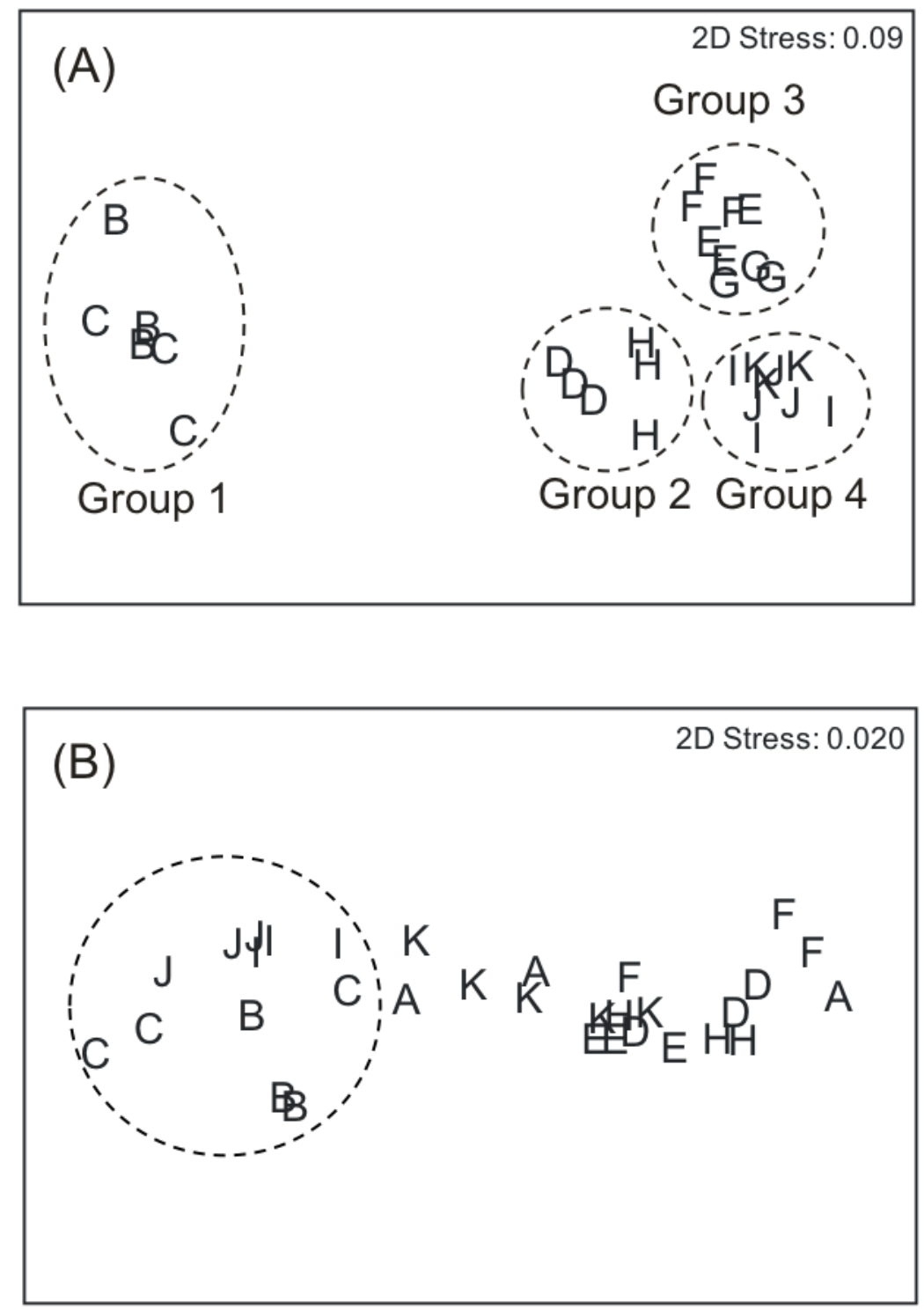

Figure 5. Two dimensional MDS ordination of (A) macrofaunal (grab samples, square root transformed) and (B) meiofaunal (raw counts) community composition based on taxa abundance. Circles denote statistically distinctive site clusters determined in SIMPROF $(p<0.05)$.

363 Meiofauna. In contrast to the macrofauna, meiofaunal total abundance changed less along the 364 oxygen gradient (Fig. 4). Furthermore, multivariate analysis of meiofauna abundance data also did 365 not identify distinct clusters of sites related to bottom-water $\mathrm{O}_{2}$ concentration (Fig. 5b). For 366 example, cluster analysis identified a group containing sites B, C, I and J (confirmed by 367 SIMPROF), which contained in equal measures sites from the most oxic and severely hypoxic sites. 368 Significant differences in community structure among sites was in most cases (97\%) due to density 
differences of nematodes (which was the most abundant group in all samples) and harpacticoids, however the foraminiferan group Rotaliina was also responsible in a few cases.

Multivariate analyses revealed that aRPD depth and silt/clay, but not $\mathrm{O}_{2}$ concentration, were significant predictors also of meiofaunal assemblage structure (Table 3). The only other significant predictor in marginal tests was OC. Collectively, aRPD depth, silt/clay content and OC explained $48 \%$ of the variation in meiofaunal assemblage structure. High fractions of silt/clay were found at sites B, C, H, I and J. This coincided with the highest densities of nematodes, with the exception of site $\mathrm{H}$. Low levels of $\mathrm{OC}$ were found at site $\mathrm{C}$ and $\mathrm{J}$, which corresponded with the highest abundances of harpacticoids. Low aRPD values were found at sites A, B and C, which matched high abundances of nematodes, with the exception of site A.

Table 3. Proportion of variation in infaunal multivariate assemblage composition (based on replicate grab sample abundance) explained by significant correlations with (site averaged) environmental variables derived from DistLMs. Marginal tests examine a single predictor separately, while partial tests take into account the effect of the remaining predictors. There was no macrofauna at site A so it was excluded from the analysis.

\begin{tabular}{|l|l|l|l|l|}
\hline & \multicolumn{2}{|c|}{ Macrofauna } & \multicolumn{2}{c|}{ Meiofauna } \\
\hline & Marginal & Partial & Marginal & Partial \\
\hline Oxygen & $0.26 * * *$ & $0.16^{* * *}$ & & \\
\hline OC & & & $0.11^{* *}$ & $0.05 *$ \\
\hline Silt/clay & $0.19 * * *$ & $0.05 * * *$ & $0.30^{* * *}$ & $0.22 * * *$ \\
\hline aRPD & $0.28 * * *$ & $0.24 * * *$ & $0.22 * *$ & $0.21 * * *$ \\
\hline$* p<0.1, * * p<0.05, * * * p<0.01$ &
\end{tabular}

\section{Ecosystem function}

Sediment oxygen consumption and nutrient fluxes varied strongly between sites (Table 4). For further analyses, we focussed on $\mathrm{SOC}, \mathrm{NH}_{4+}$ and $\mathrm{PO}_{43}$. $\mathrm{SOC}$ increased while the $\mathrm{PO}_{43}$ - flux showed a general decrease with increasing bottom-water $\mathrm{O}_{2}$ concentration, also when averaged between the sites corresponding to the groups identified based on the macrofaunal communities (Fig. 6). The 
$\mathrm{NH}_{4+}$ flux was highly variable with no clear relationship with $\mathrm{O}_{2}$ concentration, but similar to $\mathrm{PO}_{43-}$, there was a large efflux at the almost anoxic site A.

Table 4. Sediment $\mathrm{O}_{2}$ consumption ( $\left.\mathrm{ml} \mathrm{m-2} \mathrm{d}-1\right)$ and nutrient fluxes ( $\left.\mu \mathrm{mol} \mathrm{m}-2 \mathrm{~d}-1\right)$ across the sediment-water interface at the study sites in the Havstensfjord and Askeröfjord, sampled in September (average \pm SD, five replicate flux cores per site). Negative values denote an influx into the sediment. Unfortunately, the $\mathrm{NH}_{4+}$ samples from sites $\mathrm{B}, \mathrm{E}$ and $\mathrm{J}$ went missing during analysis.

\begin{tabular}{|ccccccc|}
\hline Site & $\mathrm{O}_{2}$ & $\mathrm{NO}_{3-}$ & $\mathrm{NO}_{2-}$ & $\mathrm{NH}_{4+}$ & $\mathrm{PO}_{43-}$ & $\mathrm{SiO}_{4}$ \\
& & & & & & \\
$\mathrm{~A}$ & $73 \pm 94$ & $8 \pm 65$ & $1 \pm 20$ & $2473 \pm 809$ & $3554 \pm 1756$ & $3128 \pm 2544$ \\
$\mathrm{~B}$ & $-48 \pm 66$ & $-1138 \pm 128$ & $-50 \pm 65$ & - & $298 \pm 162$ & $2092 \pm 908$ \\
$\mathrm{C}$ & $-79 \pm 117$ & $752 \pm 2219$ & $57 \pm 116$ & $473 \pm 409$ & $442 \pm 490$ & $6323 \pm 6034$ \\
$\mathrm{D}$ & $-109 \pm 37$ & $-737 \pm 110$ & $-98 \pm 19$ & $910 \pm 425$ & $268 \pm 108$ & $3173 \pm 688$ \\
$\mathrm{E}$ & $-124 \pm 21$ & $-440 \pm 241$ & $-130 \pm 17$ & - & $199 \pm 89$ & $2495 \pm 514$ \\
$\mathrm{~F}$ & $-61 \pm 66$ & $-571 \pm 228$ & $-110 \pm 14$ & $132 \pm 304$ & $91 \pm 52$ & $1789 \pm 769$ \\
$\mathrm{G}$ & $-149 \pm 34$ & $-1179 \pm 208$ & $-176 \pm 31$ & $244 \pm 164$ & $112 \pm 100$ & $3130 \pm 254$ \\
$\mathrm{H}$ & $-100 \pm 128$ & $-911 \pm 2521$ & $-86 \pm 154$ & $208 \pm 278$ & $25 \pm 314$ & $1022 \pm 6574$ \\
$\mathrm{I}$ & $-227 \pm 76$ & $-1323 \pm 235$ & $-178 \pm 8$ & $1274 \pm 401$ & $130 \pm 82$ & $5188 \pm 1143$ \\
$\mathrm{~J}$ & $-124 \pm 45$ & $-116 \pm 63$ & $-76 \pm 28$ & - & $97 \pm 51$ & $2273 \pm 899$ \\
$\mathrm{~K}$ & $-431 \pm 74$ & $80 \pm 178$ & $-13 \pm 14$ & $494 \pm 315$ & $43 \pm 35$ & $3103 \pm 1842$ \\
& & & & & & \\
\hline
\end{tabular}

In the DistLM we used the same four independent site environmental variables as above for the community analyses (depth, $\mathrm{O}_{2}$ concentration (core specific, i.e. concentration at start of incubation), aRPD, OC and silt/clay), and the following faunal variables: core specific macrofauna abundance, biomass (less Arctica) and Shannon diversity and the site-averaged meiofaunal abundance and Shannon diversity. We did not include the number of taxa as a predictor variable because for macrofauna it was highly correlated with abundance (Pearson's $r>0.8$ ) and the number of meiofauna taxa did not vary among sites. Site A was omitted from analyses because of the absence of macrofauna and predominantly chemically driven changes to measured fluxes, particularly for $\mathrm{NH}_{4+}$ and $\mathrm{PO}_{43}$-. Unfortunately, the $\mathrm{NH}_{4+}$ samples from sites $\mathrm{B}, \mathrm{E}$ and $\mathrm{J}$ went missing during analysis and so the DistLM analysis were conducted on a reduced set of sites. Fortunately, the missing sites were scattered across the oxygen gradient. 

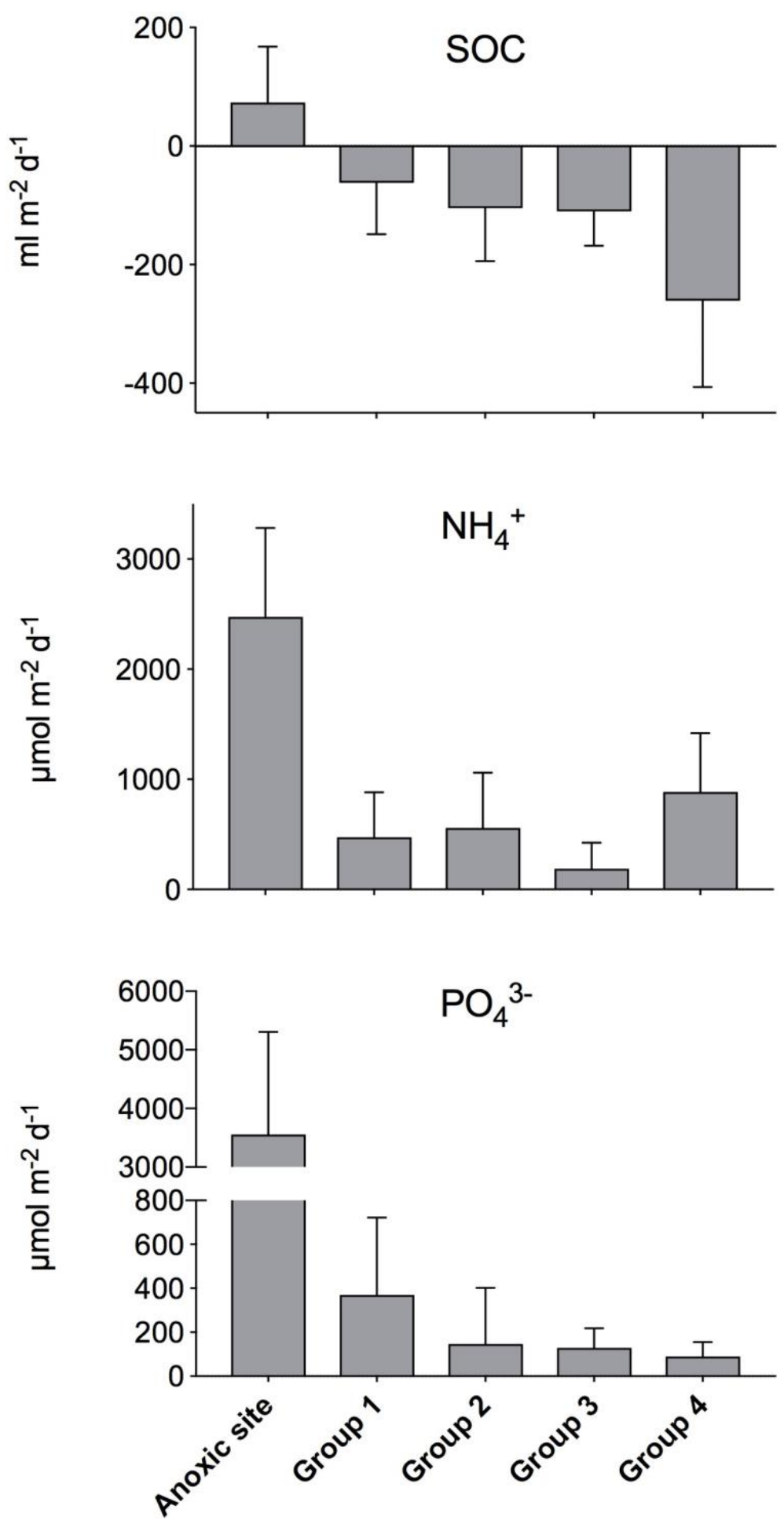

414 Figure 6. Sediment oxygen consumption (SOC) and effluxes of $\mathrm{NH}_{4+}$ and $\mathrm{PO}_{43}$ - (average $\pm \mathrm{SD}$ ) in 415 the site groupings identified based on multivariate analyses of macrofaunal abundances (Fig. 5), 416 where Group 1 = severely hypoxic, Group 4 = Oxic. In addition, data from the almost anoxic site 417 (site A) is included. 
$419 \mathrm{O}_{2}$ concentration was the single best predictor of SOC closely followed by macrofaunal abundance, 420 both being positively correlated to SOC (Table 5). Depth, macrofaunal biomass and meiofaunal 421 diversity were also correlated with SOC in marginal tests however in partial tests, after fitting other 422 significant predictors first, they did not explain a significant amount of the residual variation. The 423 single best linear combination of variables included $\mathrm{O}_{2}$ concentration and macrofaunal abundance 424 which collectively explained $63 \%$ of the variation in SOC. Inclusion of the remaining predictors 425 only explained an additional $3 \%$ of the variability.

The reduced number of sites included in the analysis of $\mathrm{NH}_{4+}$ flux restricted the environmental gradient and as a consequence no water or sediment environmental variables were significant predictors. Macrofaunal biomass was the single best predictor of $\mathrm{NH}_{4+}$ flux followed by macrofaunal abundance then meiofaunal abundance, all being positively correlated to the $\mathrm{NH}_{4+}$ flux

431 (Table 5). In partial tests both macrofaunal biomass and meiofaunal abundance were still significant, but macrofaunal abundance was not due it being correlated (albeit weakly) with biomass. Macrofaunal biomass and meiofaunal abundance collectively explained $30 \%$ of the 434 variation in $\mathrm{NH}_{4+}$ flux.

In marginal tests the $\mathrm{PO}_{43}$ - flux was best correlated with $\mathrm{O}_{2}$ concentration with higher fluxes associated with lower $\mathrm{O}_{2}$ concentrations (Table 5). Phosphate flux was weakly correlated with most 438 faunal predictors. Interestingly, while the flux was negatively correlated with measures of 439 macrofaunal community composition it was positively correlated with meiofaunal indices. This 440 relationship is explained in part by decline in macrofaunal abundance/biomass with decreasing $\mathrm{O}_{2}$ 441 concentration. In partial tests only $\mathrm{O}_{2}$ concentration, macrofaunal biomass and meiofaunal 442 abundance were significant predictors of phosphate flux and combined explained $28 \%$ of the 443 variability in the data. 
Table 5. Proportion of variation in sediment oxygen consumption (SOC), $\mathrm{NH}_{4+\text { and }} \mathrm{PO}_{43}$ - flux explained by significant correlations with faunal/environmental variables (the direction is given in brackets) derived from DistLMs. Marginal tests examine a single predictor separately, while partial tests take into account the effect of the remaining predictors. There was no macrofauna at site A so it was excluded from the analysis.

\begin{tabular}{|l|l|l|l|l|l|l|}
\hline & \multicolumn{2}{|c|}{ SOC } & \multicolumn{2}{c|}{$\mathrm{NH}_{4+}$} & \multicolumn{2}{c|}{ PO43- } \\
\hline & Marginal & Partial & Marginal & Partial & Marginal & Partial \\
\hline Depth & $0.23^{* * *(-)}$ & 0.02 & & & & \\
\hline Oxygen & $0.57 * * *(+)$ & $0.14 * * *$ & & & $0.13^{* *(-)}$ & $0.07 * *$ \\
\hline Macro-d & $0.41^{* * *(+)}$ & $0.05^{* *}$ & $0.13^{* *(+)}$ & 0.04 & $0.10^{* *(-)}$ & $<0.01$ \\
\hline Macro-b & $0.07 *(+)$ & 0.02 & $0.23^{* * *}(+)$ & $0.06^{*}$ & $0.06^{*}(-)$ & $0.05^{*}$ \\
\hline Macro-H' & & & & & $0.11^{* *(-)}$ & $<0.01$ \\
\hline Meio-d & & & $0.11^{*}(+)$ & $0.09 *$ & $0.11^{* *(+)}$ & $0.07 * *$ \\
\hline Meio-H' & $0.13^{* *}(+)$ & 0.01 & & & $0.13^{* *(+)}$ & 0.02 \\
\hline
\end{tabular}

Macro-d = abundance of macrofauna core-1, Macro-b = g ww core-1, Macro-H' the Shannon diversity, Meio- $d=$ meiofaunal abundance g sediment-1

$* p<0.1, * * p<0.05, * * * p<0.01$

\section{DISCUSSION}

The deleterious effects of hypoxia on macrofaunal communities are well known and our results from the seasonally hypoxic Havstensfjord and Askeröfjord corroborate this pattern, with a general decrease in macrofaunal species richness, abundance and biomass with decreasing bottom-water $\mathrm{O}_{2}$ concentration. Meiofaunal communities on the other hand did not appear to be similarly affected by hypoxia (Table 3). Bottom-water $\mathrm{O}_{2}$ concentration was the most important factor explaining variation in sediment oxygen consumption (SOC) and fluxes of $\mathrm{NH}_{4+a n d} \mathrm{PO}_{43}$-. Nevertheless, after the key gradient in oxygen had been accounted for, macrofauna and meiofauna explained a small but significant fraction of the variation in ecosystem function. This implies that faunal burrowing and feeding indeed affect nutrient cycling, also when bottom-water concentrations are low, i.e. this is not a purely geochemically driven process. For example, the burrowing enhances the oxygenation of the sediment, thereby reducing the $\mathrm{PO} 43$ - efflux. The nearly anoxic site A was markedly different to the other sites, with no macrofauna and with massive effluxes of $\mathrm{PO}_{43}$ - and $\mathrm{NH}_{4+}$ from the 
sediment (up to an order of magnitude higher fluxes than at other sites), indicating a complete shift to geochemically-driven functioning.

The patterns of structural changes in macrofaunal communities following organic enrichment and ensuing hypoxia have been well known for several decades (Pearson and Rosenberg 1978), but the link to changes in ecosystem functioning remains elusive. The SPI analysis showed that the depth of the aRPD was shallowest at the almost anoxic site and generally deeper at more oxic sites, but not consistently (Table 1). The aRPD can indeed be used as a proxy for the transition between redox states (Rosenberg et al. 2001, Simone and Grant 2017), but while it was a significant predictor of both macrofauna and meiofauna (Table 3; although macrofauna activity is likely also affecting the depth of the aRPD, so the interaction works both ways), it was not an important predictor for $\mathrm{SOC}$ or fluxes of $\mathrm{NH}_{4+}$ or $\mathrm{PO}_{43}$ - (Table 5). Neither did the $\mathrm{BHQ}$ index correspond to the nutrient fluxes, as it was a too coarse measure, with all our sites (except A) classified to the two highest successional stages (BHQ 5-10 and >10). The multivariate analysis of macrofauna community abundance, on the other hand, split these sites into four groups (in addition to site A). There were indications that the four site clusters identified had a relationship with SOC and PO $43-$ fluxes (Fig. 6), with increasing SOC and decreasing PO43- flux towards the more oxic groups. The four most abundant species were common in three of the four groups identified, indicating a high level of tolerance to hypoxia. These species live buried in the sediment and have a generation time of one year or more, and none of them are among the first colonizers in a succession pattern like Capitella and Polydora. It is possible that such tolerant species might uphold bioturbation throughout the year in seasonally hypoxic areas, although seasonal patterns in species-specific bioturbation activity are not known. The number of sites (11 in total, 2-3 sites per group) did not, however, allow analysing in detail any between-group differences in the different factors explaining the variability of the fluxes. Future studies are needed to address this. 
Hypoxia, benthic fauna and nutrient cycling

494 The Havstensfjord has suffered from seasonal hypoxia since the 1950s and the most likely cause is eutrophication (Nilsson and Rosenberg 1997). Given the long history of hypoxic stress, the benthic communities are probably adapted to this disturbance, but also likely permanently somewhat degraded compared with communities that have not been exposed to hypoxia. Undisturbed communities would likely be characterised by higher species richness, and large-bodied and longlived species (Pearson and Rosenberg 1978, Diaz and Rosenberg 1995, Gray et al. 2002), with a potential for a stronger, more direct impact on nutrient cycling. The bottom-water $\mathrm{O}_{2}$ concentration was indeed relatively low at all sites at the time of sampling. The benthic habitat quality in relation to hypoxia has previously (in 1994) been studied in the fjord using SPI (Nilsson and Rosenberg 1997), and no major changes in aRPD or further degradation of the BHQ index were observed in

504 the current study. Thus, the Havstensfjord appears to have been in a stable state of seasonal hypoxia 505 for decades already, with periods of good conditions every year. The big individuals of the bivalve Arctica islandica found in the two hypoxic groups indicate that there had not been long periods of complete anoxia at these sites in the last few years before the sampling, although these bivalves can reduce metabolism and survive several months in hypoxic conditions. Given the proportionately larger influence on nutrient cycling of such large individuals (Norkko et al. 2013), these few bivalves may have a significant effect on ecosystem functioning in-between the hypoxic periods.

512 Fjords and other enclosed inlets and seas are prone to hypoxia because of limited water exchange.

513 Once a system has passed the threshold to hypoxia, the reversal might be difficult (Conley et al. 514 2009b), and there is evidence that once an ecosystem experiences hypoxia, it might be more 515 susceptible to hypoxia in the future (Conley et al. 2007, Diaz and Rosenberg 2008). This poses 516 challenges for the management of these systems. Another methodological challenge is often 517 introduced as part of the monitoring of hypoxia. We used the $\mathrm{O}_{2}$ concentration measured 2-3 cm 
Hypoxia, benthic fauna and nutrient cycling

518 above the sediment surface in flux chambers immediately upon core retrieval for the statistical

519 analyses. It is important to consider the difference between these concentrations and the ones

520 measured $1 \mathrm{~m}$ (or even higher with big CTD rosettes) above the sediment surface in most

521 monitoring programmes (Rosenberg 1977). Due to the benthic boundary layer processes, where

522 decreasing flow closer to the sediment surface usually corresponds to decreasing $\mathrm{O}_{2}$ concentrations

523 (e.g., Jørgensen and Des Marais 1990), the monitoring data does not necessarily reflect the real

524 near-bottom $\mathrm{O}_{2}$ concentrations, which hampers modelling efforts to predict species distribution

525 patterns in relation to $\mathrm{O}_{2}$ conditions (Virtanen et al. 2019).

Temperature, salinity, and near-bottom $\mathrm{O}_{2}$ concentrations were strongly correlated and therefore only $\mathrm{O}_{2}$ was included in the statistical analysis. Since all three variables can affect community structure as well as ecosystem function, we cannot rule out the potential impact of co-variables, but we cannot disentangle these effects from our field sampling because the hypoxic water was deep,

531 beneath the thermocline and therefore salty and/or cold. However, the lack of oxygen will most 532 likely override the effects of the other two on nutrient cycling, as it stresses the fauna as well as 533 alters biogeochemical pathways. While oxygen dropped below detrimental levels in this study, 534 neither the range in salinity (25-32) nor temperature (7-15) is likely to be a major driver of the 535 differences in function observed, given that this is an estuarine environment with organisms adapted 536 to fluctuations. It should also be noted, that in this relatively cool fjord system organisms are more 537 likely to oxyregulate and the effects of hypoxia may be therefore be less stressful compared to 538 warmer systems, where organisms are more likely to experience metabolic depression, i.e. 539 oxyconformation (Pörtner et al. 2005). Temperature does, however, affect nutrient fluxes, with 540 higher reaction rates at warmer temperatures. In our study, the bottom-water temperature varied 541 from 7 to 15 degrees, and the incubations were done at a standard 11 degrees, so it is possible that 
the fluxes at the shallowest and the deepest site were slightly underestimated and overestimated, respectively. This would, however, not have affected the main conclusions.

The importance of macrofauna for explaining variability in SOC and nutrient fluxes in the current study was similar to that found across gradients of increasing hypoxia by Gammal et al. (2017) and (Norkko et al. 2015), in the coastal and open Baltic Sea, respectively. This indicates that the number of species is not crucial for functioning; the Baltic is very species poor (open sea often only 5-7 species) compared with the Swedish west coast (up to 40 species recorded per grab in the current study). This is contrary to our prediction that the effect of hypoxia on the faunal contribution to functioning would be smaller in a system with a higher background diversity. The number of macrofaunal species was highly correlated with the macrofaunal abundance, further indicating that 553 the number of species is not the sole driving factor for functioning. Indeed, in previous studies under normoxic conditions it has been suggested that species-specific traits of some particularly important individual species, for example, the sediment reworking by large and abundant burrowing urchins or bivalves, may override both species richness and functional diversity in terms of influencing benthic nutrient cycling (Lohrer et al. 2004, Norling et al. 2007, Norkko et al. 2013).

Of particular interest is then whether the fauna can still contribute to ecosystem functioning when conditions deteriorate, i.e. before the fauna is decimated, but when physiological and behavioural 561 changes are already likely to have been initiated. Hypoxia tolerance is highly species specific 562 (Vaquer-Sunyer and Duarte 2008), with potential for changes in behaviour already at relatively high $563 \mathrm{O}_{2}$ concentrations. For example, urchin grazing rates dropped already at $5.5 \mathrm{mg} / \mathrm{L}(3.85 \mathrm{ml} \mathrm{L}-1)$, 564 with potential consequences on kelp recruitment (Low and Micheli 2018). Macrofauna can still 565 influence nutrient cycling in low $\mathrm{O}_{2}$ conditions, although not as much as under good $\mathrm{O}_{2}$ conditions 566 (Norkko et al. 2015). This points to the increasing importance of tolerant species when conditions 
deteriorate, e.g. the invasive polychaete Marenzelleria spp. in the Baltic Sea (Norkko et al. 2015).

568 Such deep-burrowing species may also affect the propensity for rapid oxygen consumption by

569 burying organic matter deeper into the sediment, which slows down the oxidation of OM (Josefson

570 et al. 2012). Other studies have also found that larger-bodied, tolerant species may mediate

571 ecosystem functioning during periods of low-oxygen conditions (Rakocinski and Menke 2016). In

572 the present study the large bivalve Arctica islandica may have performed this role. Nevertheless,

573 the hypoxia-induced changes in species behaviour that is influencing nutrient cycling are not

574 sufficiently known and this requires further mechanistic studies.

\section{Meiofauna, microbes and altered energy pathways}

577 The differences in meiofaunal communities were due to the silt/clay fraction, OC and aRPD, not

578 differences in $\mathrm{O}_{2}$ concentrations, which was the major factor explaining differences in the

579 macrofauna. Various taxa of meiofauna can use aerobic metabolism at $\mathrm{O}_{2}$ concentrations as low as

$580 \quad 0.1 \mu \mathrm{mol} / \mathrm{l}$ (Giere 2009). In addition, the non-correlation to $\mathrm{O}_{2}$ concentration has been noted before,

581 by e.g. Josefson and Widbom (1988), who recorded no major decrease of any meiofaunal taxa

582 during a several month long period of anoxia in the Gullmar Fjord, Sweden. In the Baltic Sea,

583 Elmgren (1975) noted that meiofauna did decrease with decreasning oxygen conditions, but that the

584 meiofauna extended deeper into the hypoxic zone compared with the macrofauna. In the current

585 study the aRPD, which approximates the depth of the oxygenated sediment layer, also significantly

586 affected the differences in meiofaunal community structure, and thus $\mathrm{O}_{2}$ is probably still involved in

587 the vertical distribution of the meiofauna, possibly through indirect effects on macrofaunal

588 bioturbation. Sediments with high silt/clay fractions have a lower permeability compared to coarser

589 sediments, which directly influences the amount of oxygenated water that can penetrate into the

590 sediment. Large abundances of nematodes were found at the sites with a high silt/clay fraction (B,

$591 \mathrm{C}, \mathrm{H}, \mathrm{I}, \mathrm{J})$, which is a common representation. The nematode community is then often made up of 
Hypoxia, benthic fauna and nutrient cycling

non-selective deposit-feeding nematodes grazing on bacteria and detritus (Heip et al. 1985, Boeckner et al. 2009, Delgado et al. 2009). Larger grain size tends to lead to more harpacticoids; however they can thrive in various conditions (Giere 2009).

At site $\mathrm{B}$ and $\mathrm{J}$ high levels of $\mathrm{NH}_{4+}$ were registered. It is also at these sites the highest abundances of meiofauna were found. This relationship can be stressed further using site $\mathrm{H}$, which had low $\mathrm{NH}_{4+}$ while at the same time holding one of the lowest total meiofaunal abundances of the analyzed sites. The high ammonium at site $\mathrm{B}$ and $\mathrm{C}$ can furthermore be explained by a reduced bioturbation under the anoxic conditions at those sites. This can in its turn affect the nitrification and denitrification; instead of nitrogen being removed as $\mathrm{N}_{2}$ in denitrification processes, ammonia, ammonium and phosphate are the main fluxes out of the sediment (Diaz and Rosenberg 2008). In addition, meiofauna is known not to control the abundance of the microbial community with their grazing, but to enhance the growth rate (Piot et al. 2014). In general, high OC leads to higher abundances of meiofauna but at the sites in this survey the relationship was reversed. Nevertheless, no site had very low OC (range $7.7-12 \%$ ) and OC was likely not a limiting factor for the meiofauna.

Prolonged hypoxia will have larger-scale functional consequences, with miniaturization of benthic food webs and altered energy pathways (the last successional stages 1 and 0) (Diaz and Rosenberg 2008). For example, deep-burrowing species which are important for organic matter processing, priming it for further processing by the microbes, will be lost (Table 2), translating also into a loss of functional spaces and a reduction of surface area. While our study design did not allow for quantifying this, it is possible that meiofaunal and microbial communities will have a proportionately larger influence on ecosystem function in stressed systems compared with macrofauna. The resistance of sediment microbial communities to hypoxia is however poorly known, but field experiments with in situ -induced hypoxia indicated that microbial diversity 
Hypoxia, benthic fauna and nutrient cycling

617 decreased with increasing duration of hypoxic stress, concurrently with the deteriorating

618 macrofaunal community, likely due to the reduced macrofaunal bioturbation activity (Sinkko et al.

619 submitted).

621 Conclusions and management implications

622 Many studies on BEF have failed to demonstrate real-world relevance, highlighting the need to 623 combine insights derived from theory with detailed experiments and broad-scale monitoring and 624 well-designed field surveys (Snelgrove et al. 2014). While causality cannot be assigned in 625 correlative field studies, they are imperative for understanding the generality of the BEF 626 relationships. They need to be conducted in a range of different environments and geographical 627 areas, using the same methodology and focussing on the relative similarities or differences. There 628 are however inherent logistic constraints to field work, as the number of sites that it is possible to 629 include in a field study is almost always limited.

631 Ecosystem management decisions are based on model predictions of key ecosystem processes.

632 While our understanding of the links between biodiversity and ecosystem functioning, also under 633 increasing hypoxia, is growing, there are still large gaps in our knowledge about these processes 634 and how they can be included in the models, with significant effects on model performance 635 (Carstensen et al. 2014). For example, while there are sophisticated models used for nutrient 636 management around the entire Baltic Sea (BALTSEM; Savchuk et al. 2012), macrofauna data is 637 currently lacking altogether from these models, which is a serious drawback for being able to 638 predict, for example, the time required for recovery of the sea from eutrophication. Indeed our 639 failure to account for biodiversity in models of biogeochemical cycling is severely impeding our 640 ability to understand, quantify and predict, the consequences of changes in eutrophication status and 641 climate as expressed through altered carbon pathways (Snelgrove et al. 2018). This work thus needs 
Hypoxia, benthic fauna and nutrient cycling

642 to continue with field studies targeting macrofauna, meiofauna as well as microbes linked with

643 controlled laboratory studies where specific mechanisms can be quantified, conducted in parallel 644 with model development. This will become increasingly important as we grapple with trying to 645 protect the dwindling biodiversity and trying to predict future changes in ecosystem functioning. 
Hypoxia, benthic fauna and nutrient cycling

\section{ACKNOWLEDGEMENTS}

The study was supported by an ASSEMBLE grant (European Community, ASSEMBLE grant agreement 227799), the BONUS+ HYPER project (FP7/2007-2013, grant agreement 217246), the Walter and Andrée de Nottbeck Foundation, Victoriastiftelsen and the Academy of Finland (project ID 294853). We thank the crew on-board R/V Skagerak for help with sampling, the Sven Lovén Centre for Marine Sciences, Kristineberg, for laboratory facilities, and Pia Engström for help with preparations.

\section{Role of the funding source}

The funders had no influence on the execution of the study or the preparation of this article.

\section{REFERENCES}

Aller, RC, JY Aller. 1998. The effect of biogenic irrigation intensity and solute exchange on diagenetic reaction rates in marine sediments. J. Mar. Res. 56:905-936.

Anderson, MJ, RN Gorley, KR Clarke. 2008. PERMANOVA+ for PRIMER. Guide to software and statistical methods.

Boeckner, MJ, J Sharma, HC Proctor. 2009. Revisiting the meiofauna paradox: dispersal and colonization of nematodes and other meiofaunal organisms in low- and high-energy environments. Hydrobiologia 624:91-106.

Bonaglia, S, FJA Nascimento, M Bartoli, I Klawonn, V Bruchert. 2014. Meiofauna increases bacterial denitrification in marine sediments. Nature Communications 5.

Breitburg, D, LA Levin, A Oschlies, M Gregoire, FP Chavez, DJ Conley, V Garcon, D Gilbert, D Gutierrez, K Isensee, GS Jacinto, KE Limburg, I Montes, SWA Naqvi, GC Pitcher, NN Rabalais, MR Roman, KA Rose, BA Seibel, M Telszewski, M Yasuhara, J Zhang. 2018. Declining oxygen in the global ocean and coastal waters. Science 359:eaam7240. 
Burgess, R. 2001. An improved protocol for separating meiofauna from sediments using colloidal silica sols. Mar. Ecol. Prog. Ser. 214:161-165.

Carstensen, J, DJ Conley, E Bonsdorff, BG Gustafsson, S Hietanen, U Janas, T Jilbert, A Maximov, A Norkko, J Norkko, DC Reed, CP Slomp, K Timmermann, M Voss. 2014. Hypoxia in the Baltic Sea: Biogeochemical cycles, benthic fauna and management. Ambio 43:26-36.

Chapin III, FS, BH Walker, RJ Hobbs, DU Hooper, JH Lawton, OE Sala, D Tilman. 1997. Biotic control over the functioning of ecosystems. Science 277:500-504.

Clarke, KR. 1993. Non-parametric multivariate analyses of changes in community structure. Aust. J. Ecol. 18:117-143.

Clarke, KR, RN Gorley. 2006. PRIMER v6: User Manual / Tutorial. PRIMER-E, Plymouth. Conley, DJ, S Björck, E Bonsdorff, J Carstensen, G Destouni, BG Gustafsson, S Hietanen, M Kortekaas, H Kuosa, HEM Meier, B Müller-Karulis, K Nordberg, A Norkko, G Nürnberg, H Pitkänen, NN Rabalais, R Rosenberg, OP Savchuk, CP Slomp, M Voss, F Wulff, L Zillén. 2009a. Hypoxia-related processes in the Baltic Sea. Environ. Sci. Technol. 43:3412-3420.

Conley, DJ, E Bonsdorff, J Carstensen, G Destouni, BG Gustafsson, L-A Hansson, NN Rabalais, M Voss, L Zillén. 2009b. Tackling hypoxia in the Baltic Sea: Is engineering a solution? Environ. Sci. Technol. 43:3407-3411.

Conley, DJ, J Carstensen, G Ærtebjerg, PB Christensen, T Dalsgaard, JLS Hansen, AB Josefson. 2007. Long-term changes and impacts of hypoxia in Danish coastal waters. Ecol. Appl. 17:S165S184.

Conley, DJ, J Carstensen, J Aigars, P Axe, E Bonsdorff, T Eremina, B-M Haahti, C Humborg, P Jonsson, J Kotta, C Lännergren, U Larsson, A Maximov, M Rodriguez Medina, E LysiakPastuszak, N Remeikaite-Nikiene, J Walve, S Wilhelms, L Zillén. 2011. Hypoxia is increasing in the coastal zone of the Baltic Sea. Environ. Sci. Technol. 45:6777-6783. 
Cowan, JLW, WR Boynton. 1996. Sediment-water oxygen and nutrient exchanges along the longitudinal axis of Chesapeake Bay: Seasonal patterns, controlling factors and ecological significance. Estuaries 19:562-580.

Delgado, JD, R Riera, Ó Monterroso, J Núñez. 2009. Distribution and abundance of meiofauna in intertidal sand substrata around Iceland. Aquat. Ecol. 43:221-233.

Diaz, RJ, R Rosenberg. 1995. Marine benthic hypoxia: a review of its ecological effects and the behavioural responses of benthic macrofauna. Oceanogr. Mar. Biol. Annu. Rev. 33:245-303.

Diaz, RJ, R Rosenberg. 2008. Spreading dead zones and consequences for marine ecosystems. Science 321:926-929.

Elmgren, R. 1975. Benthic meiofauna as indicator of oxygen conditions in the northern Baltic Proper. Merentutkimuslaitoksen julkaisuja 239:265-271.

Friedrich J, F Janssen, D Aleynik, HW Bange, NBoltacheva, MN Çagatay, AW Dale, G Etiope, Z Erdem, M Geraga, A Gilli, MT Gomoiu, POJ Hall, D Hansson, Y He, M Holtappels, MK Kirf, M Kononets, S Konovalov, A Lichtschlag, DM Livingstone, G Marinaro, S Mazlumyan, S Naeher, RP North, G Papatheodorou, O Pfannkuche, R Prien, G Rehder, CJ Schubert, T Soltwedel, S Sommer, H Stahl, EV Stanev, A Teaca, A Tengberg, C Waldmann, B Wehrli, F Wenzhöfer. 2014. Investigating hypoxia in aquatic environments: diverse approaches to addressing a complex phenomenon. Biogeosciences 11:1215-1259.

Gammal, J, J Norkko, CA Pilditch, A Norkko. 2017. Coastal hypoxia and the importance of benthic macrofauna communities for ecosystem functioning. Estuar. Coast. 40:457-468.

Giere, O. 2009. Meiobenthology: The microscopic motile fauna of aquatic sediments. 2nd edition. Springer-Verlag, Berlin.

Glud, RN. 2008. Oxygen dynamics of marine sediments. Mar. Biol. Res. 4:243-289.

Gray, JS, RSS Wu, YY Or. 2002. Effects of hypoxia and organic enrichment on the coastal marine environment. Mar. Ecol. Prog. Ser. 238:249-279. 
Hypoxia, benthic fauna and nutrient cycling

Halpern, BS, S Walbridge, KA Selkoe, CV Kappel, F Micheli, C D’Agrosa, JF Bruno, KS Casey, C Ebert, HE Fox, R Fujita, D Heinemann, HS Lenihan, EMP Madin, MT Perry, ER Selig, M Spalding, R Steneck, R Watson. 2008. A global map of human impact on marine ecosystems. Science 319:948-952.

Hansson, D, A Stigebrandt, B Liljebladh. 2013. Modelling the Orust fjord system on the Swedish west coast. J. Mar. Syst. 113:29-41.

Heip, C, M Vincx, G Vranken. 1985. The ecology of marine nematodes. Oceanogr. Mar. Biol. Annu. Rev. 23:399-489.

Ingall, ED, RM Bustin, P Van Cappellen. 1993. Influence of water column anoxia on the burial and preservation of carbon and phosphorus in marine shales. Geochim. Cosmochim. Acta 57:303316.

Jäntti, H, S Hietanen. 2012. The effects of hypoxia on sediment nitrogen cycling in the Baltic Sea. Ambio 41:161-169.

Jørgensen, BB, DJ Des Marais. 1990. The diffusive boundary layer of sediments: Oxygen microgradients over a microbial mat. Limnol. Oceanogr. 35:1343-1355.

Josefson, AB, J Norkko, A Norkko. 2012. Burial and decomposition of plant pigments in surface sediments of the Baltic Sea - role of oxygen and benthic fauna. Mar. Ecol. Prog. Ser. 455:33-49. Josefson, AB, B Widbom. 1988. Differential response of benthic macrofauna and meiofauna to hypoxia in the Gullmar Fjord basin. Mar. Biol. 100:31-40.

Levin, LA, DF Boesch, A Covich, C Dahm, C Erséus, KC Ewel, RT Kneib, A Moldenke, MA Palmer, P Snelgrove, D Strayer, JM Weslawski. 2001. The function of marine critical transition zones and the importance of sediment biodiversity. Ecosystems 4:430-451.

Levin, LA, W Ekau, AJ Gooday, F Jorissen, JJ Middelburg, SWA Naqvi, C Neira, NN Rabalais, J Zhang. 2009. Effects of natural and human-induced hypoxia on coastal benthos. Biogeosciences 6:2063-2098. 
Levinton, J. 1995. Bioturbators as ecosystem engineers: Control of the sediment fabric, interindividual interactions, and material fluxes. Pages 29-38 in C. G. Jones and J. H. Lawton, editors. Linking species and ecosystems. Chapman \& Hall, New York.

Lindgren, JF, IM Hassellov, I Dahllof. 2013. Analyzing changes in sediment meiofauna communities using the image analysis software ZooImage. J. Exp. Mar. Biol. Ecol. 440:74-80.

Lohrer, AM, SF Thrush, MM Gibbs. 2004. Bioturbators enhance ecosystem function through complex biogeochemical interactions. Nature 431:1092-1095.

Low, NHN, F Micheli. 2018. Lethal and functional thresholds of hypoxia in two key benthic grazers. Mar. Ecol. Prog. Ser. 594:165-173.

McCarthy, MJ, KS McNeal, JW Morse, WS Gardner. 2008. Bottom-water hypoxia effects on sediment-water interface nitrogen transformations in a seasonally hypoxic, shallow bay (Corpus christi bay, TX, USA). Estuar. Coast. 31:521-531.

Meysman, FJR, JJ Middelburg, CHR Heip. 2006. Bioturbation: a fresh look at Darwin's last idea. Trends Ecol. Evol. 21:688-695.

Middelburg, JJ, LA Levin. 2009. Coastal hypoxia and sediment biogeochemistry. Biogeosciences 6:1273-1293.

Mortimer, CH. 1941. The exchange of dissolved substances between mud and water in lakes. J. Ecol. 29:280-329.

Nilsson, HC, R Rosenberg. 1997. Benthic habitat quality assessment of an oxygen stressed fjord by surface and sediment profile images. J. Mar. Syst. 11:249-264.

Norkko, A, A Villnäs, J Norkko, S Valanko, CA Pilditch. 2013. Size matters: implications of the loss of large individuals for ecosystem function. Sci. Rep. 3:2646.

Norkko, J, J Gammal, JE Hewitt, AB Josefson, J Carstensen, A Norkko. 2015. Seafloor ecosystem function relationships: In situ patterns of change across gradients of increasing hypoxic stress. Ecosystems:1-16. 
Norling, K, R Rosenberg, S Hulth, A Grémare, E Bonsdorff. 2007. Importance of functional biodiversity and species-specific traits of benthic fauna for ecosystem functions in marine sediment. Mar. Ecol. Prog. Ser. 332:11-23.

Pearson, TH, R Rosenberg. 1978. Macrobenthic succession in relation to organic enrichment and pollution of the marine environment. Oceanogr. Mar. Biol. Annu. Rev. 16:229-311.

Piot, A, C Nozais, P Archambault. 2014. Meiofauna affect the macrobenthic biodiversity-ecosystem functioning relationship. Oikos 123:203-213.

Pörtner, HO, M Langenbuch, B Michaelidis. 2005. Synergistic effects of temperature extremes, hypoxia, and increases in $\mathrm{CO}_{2}$ on marine animals: From Earth history to global change. J. Geophys. Res. 110:C09S10.

Rabalais, NN, W-J Cai, J Carstensen, DJ Conley, B Fry, X Hu, Z Quiñones-Rivera, R Rosenberg, CP Slomp, RE Turner, M Voss, B Wissel, J Zhang. 2014. Eutrophication-driven deoxygenation in the coastal ocean. Oceanography 27:172-183.

Rabalais, NN, RE Turner, WJ Wiseman. 2002. Gulf of Mexico hypoxia, aka "The dead zone". Annu. Rev. Ecol. Syst. 33:235-263.

Rakocinski, CF, DP Menke. 2016. Seasonal hypoxia regulates macrobenthic function and structure in the Mississippi Bight. Mar. Poll. Bull. 105:299-309.

Reed, DC, CP Slomp, BG Gustafsson. 2011. Sedimentary phosphorus dynamics and the evolution of bottom water hypoxia: A coupled benthic-pelagic model of a coastal system. Limnol. Oceanogr. 56:1075-1092.

Rosenberg, R. 1977. Benthic macrofaunal dynamics, production, and dispersion in an oxygendeficient estuary of west Sweden. J. Exp. Mar. Biol. Ecol. 26:107-133.

Rosenberg, R, S Agrenius, B Hellman, HC Nilsson, K Norling. 2002. Recovery of marine benthic habitats and fauna in a Swedish fjord following improved oxygen conditions. Mar. Ecol. Prog. Ser. 234:43-53. 
Rosenberg, R, HC Nilsson, RJ Diaz. 2001. Response of benthic fauna and changing sediment redox profiles over a hypoxic gradient. Estuar. Coast. Shelf Sci. 53:343-350.

Savchuk, OP, BG Gustafsson, B Müller-Karulis. 2012. BALTSEM - a marine model for decision support within the Baltic Sea Region.

Simone, M, J Grant. 2017. Visual assessment of redoxcline compared to electron potential in coastal marine sediments. Estuar. Coast. Shelf Sci. 188:156-162.

Slomp, CP, J Thomson, GJ de Lange. 2002. Enhanced regeneration of phosphorus during formation of the most recent eastern Mediterranean sapropel (S1). Geochim. Cosmochim. Acta 66:11711184.

Snelgrove, PVR, K Soetaert, M Solan, S Thrush, C-L Wei, R Danovaro, RW Fulweiler, H Kitazato, B Ingole, A Norkko, RJ Parkes, N Volkenborn. 2018. Global carbon cycling on a heterogeneous seafloor. Trends Ecol. Evol. 33:96-105.

Snelgrove, PVR, SF Thrush, DH Wall, A Norkko. 2014. Real world biodiversity-ecosystem functioning: a seafloor perspective. Trends Ecol. Evol. 29:398-405.

Vaquer-Sunyer, R, CM Duarte. 2008. Thresholds of hypoxia for marine biodiversity. Proceedings of the National Academy of Sciences 105:15452-15457.

Villnäs, A, A Norkko. 2011. Benthic diversity gradients and shifting baselines: implications for assessing environmental status Ecol. Appl. 21:2172-2186.

Villnäs, A, A Norkko, J Norkko, K Lukkari, J Hewitt. 2012. Impacts of increasing hypoxic disturbance on benthic biodiversity and ecosystem functioning. PLoS ONE 7:e44920.

Villnäs, A, J Norkko, S Hietanen, AB Josefson, K Lukkari, A Norkko. 2013. The role of recurrent disturbances for ecosystem multifunctionality. Ecology 94:2275-2287.

Virtanen, EA, A Norkko, A Nyström Sandman, M Viitasalo. 2019. Identifying areas prone to coastal hypoxia - the role of topography. Biogeosciences, accepted for publication. 
Hypoxia, benthic fauna and nutrient cycling

Yachi, S, M Loreau. 1999. Biodiversity and ecosystem productivity in a fluctuating environment: The insurance hypothesis. Proceedings of the National Academy of Sciences 96:1463-1468.

Yazdani Foshtomi, M, U Braeckman, S Derycke, M Sapp, D Van Gansbeke, K Sabbe, A Willems, M Vincx, J Vanaverbeke. 2015. The link between microbial diversity and nitrogen cycling in marine sediments is modulated by macrofaunal bioturbation. PLOS ONE 10:e0130116. 